\title{
The labour market by education and occupation to 2000
}

Citation for published version (APA):

Researchcentrum voor Onderwijs en Arbeidsmarkt, ROA. (1995). The labour market by education and occupation to 2000. Researchcentrum voor Onderwijs en Arbeidsmarkt, Faculteit der Economische Wetenschappen. ROA Reports No. 003E https://doi.org/10.26481/umarep.1995003E

Document status and date:

Published: 01/01/1995

DOI:

10.26481/umarep.1995003E

Document Version:

Publisher's PDF, also known as Version of record

\section{Please check the document version of this publication:}

- A submitted manuscript is the version of the article upon submission and before peer-review. There can be important differences between the submitted version and the official published version of record.

People interested in the research are advised to contact the author for the final version of the publication, or visit the DOI to the publisher's website.

- The final author version and the galley proof are versions of the publication after peer review.

- The final published version features the final layout of the paper including the volume, issue and page numbers.

Link to publication

\footnotetext{
General rights rights.

- You may freely distribute the URL identifying the publication in the public portal. please follow below link for the End User Agreement:

www.umlib.nl/taverne-license

Take down policy

If you believe that this document breaches copyright please contact us at:

repository@maastrichtuniversity.nl

providing details and we will investigate your claim.
}

Copyright and moral rights for the publications made accessible in the public portal are retained by the authors and/or other copyright owners and it is a condition of accessing publications that users recognise and abide by the legal requirements associated with these

- Users may download and print one copy of any publication from the public portal for the purpose of private study or research.

- You may not further distribute the material or use it for any profit-making activity or commercial gain

If the publication is distributed under the terms of Article $25 \mathrm{fa}$ of the Dutch Copyright Act, indicated by the "Taverne" license above, 
The labour market by education and occupation to 2000

ROA-R-1995/3E

Research Centre for Education and the Labour Market

Faculty of Economic Sciences and Business Administration University of Limburg

Maastricht, October 1995 
No part of this publication may be reproduced and/or made public made by means of printing, photocopying, microfilm, or in any other manner, without the prior written permission of the Director of the Research Centre for Education and the Labour Market. Where any of the data is used the source must be given in every case as: "Research Centre for Education and the Labour Market" or "ROA".

Although the greatest possible care has been taken as regards the contents of this report, no legal rights are implied.

ISBN 90-5321-175-6 


\section{Contents}

page

Foreword

Summary

1 An overview of the labour market $\quad 1$

2 Developments on the labour market, 1995-2000 6

2.1 Introduction 13

2.2 Expansion demand $\quad 14$

2.3 Replacement demand $\quad 23$

$\begin{array}{ll}2.4 \text { Job openings and the need for new recruits } & 30\end{array}$

2.5 Flows of school-leavers entering the labour market $\quad 35$

$\begin{array}{ll}2.6 \text { Crowding-out processes } & 38\end{array}$

3 The match between education and labour market 42

3.1 Current matching problems $\quad 42$

3.2 Labour market prospects for school-leavers 46

3.3 Future problems in the labour supply $\quad 50$

4 Substitution processes in the labour market

4.1 Introduction

4.2 Opportunities to switch within the labour market

4.3 The structure of the labour market

4.4 Sensitivity of employment to the state of the business cycle

5Developments in Intermediate Vocational Education and apprenticeship training 53

5.1 Introduction $\quad 53$

5.2 Occupations in growth or decline $\quad 54$

5.3 The match between education and labour market $\quad 57$

5.4 Sensitivity to the state of the business cycle and opportunities to switch 65

5.5 The image of the educational clusters $\quad 66$

$\begin{array}{ll}5.6 \text { Qualitative matching problems } & 70\end{array}$

5.7 Summary of the relative labour market position of Intermediate Vocational Education 72 


\section{Foreword}

The Labour Market by Education and Occupation to 2000 and its Statistical Appendix is the third version of the biannual survey which the Research Centre for Education and the Labour Market (ROA) publishes, for the Netherlands, on the basis of its information system for education and the labour market. This information system is financed by the Dutch Ministry of Education, Culture and Science, the Central Employment Board and the National Service Centre for Study and Vocational Guidance (LDC). The information system is intended to provide an insight into the current and future labour market positions of the various occupational and educational categories, with a focus on expected developments on the Dutch labour market in the medium term.

The information system focuses on medium-term labour market forecasts, in order to give those who are now making choices regarding their further studies the best possible information about the labour market situation at the time that they will enter the labour market at the completion of their studies. This public information purpose of the labour market information generated by the information system is met primarily by incorporating this data in the LDC's various information products. For instance, ROA's labour market information is included in the public information products on CD-ROM which are published in the Traject series, and in the book series Beroep en werk ('Occupation and work'). Another product which is custom-made to disseminate ROA's labour market information is the LDC publication Kansen op werk 2000, Arbeidsmarktperspectieven van opleidingen en beroepen (Chances of finding employment in 2000, labour market prospects of types of education and occupations), which was published simultaneously with the Dutch version of this report.

The target group of this report is, in the first place, those who are involved in policy-making in fields relating to the match between the education system and the labour market. Thus the report is intended particularly for the government, public employment services and local labour supply organisations, the 'social partners' (employers' organizations and the unions) and those in the educational field. In order to make a clearer differentiation between this report and LDC publications such as 'Chances of finding employment in 2000', there is no longer a focus on the significance of the labour market information for educational and vocational guidance. Four significant changes follow from this shift of emphasis:

- the forecast labour market developments are now also translated into indications of the risk of problems in the recruitment of labour with particular types of education;

-the expected labour market developments have been analyzed in more depth;

-the report now includes information by economic sector;

-explanations of the labour market information in the light of policy issues have been added.

Moreover this report shows the continuation of efforts to incorporate the wealth of information on current matching problems in the labour market, contained in two large-scale school-leavers' surveys, in the information system. These surveys are the 'RUBS' survey (Registratie Uitstroom en Bestemming van Schoolverlaters), which records the flows of school-leavers and their destinations on the labour market, and the 'Higher Vocational Education Monitor' (HBO-Monitor). The information on school-leavers from these surveys has been used especially in compiling Chapter 5 , which focuses on Intermediate Vocational Education. It can also be found in part 3 of the Statistical 
Appendix.

In coming years, efforts will be made to further improve and extend the information system. It will be especially important to fill in the gaps in the school-leaver studies by establishing a University Education Monitor (WO Monitor), to gather data on the match between supply and demand in the labour market for university graduates. As was apparent two years ago, when the first full evaluation research was carried out, it is also very important to continue with thorough evaluations of the forecasts. Accordingly, ROA's earlier labour market forecasts by education and occupation to 1994 will be evaluated soon. Action will also be taken to build on the first steps taken in this report to express the expected labour market developments in terms of an indicator of the risk of problems in recruiting labour.

This report contains little in the way of explanations of the research methods, classifications, etc. which have been used. These can be found described in ROA's specific working documents and research memoranda. The working document Methodiek van het informatiesysteem ondenwijsarbeidsmarkt 1995 (Methodology of the information system for education and the labour market 1995, ROA-W-1995/3), ${ }^{1}$ gives a complete overview of the methods used for this version of the information system. At the end of this report, a number of central concepts have been brought together and defined, with references to the publications in which more detailed information on particular points can be found.

A great deal of use has been made, in compiling this report, of the Enquête Beroepsbevolking (Labour Force Survey) of Statistics Netherlands (CBS). Under a cooperative agreement between ROA and the CBS, the data used here has been generated by ROA's staff members, working in the CBS's facilities. The CBS has imposed some restrictions regarding the publication of this data, which is one reason why no separate data is published for a number of small occupational classes and types of education with less than 5,000 workers.

The labour market forecasts by education and occupation are consistent with the forecasts which the Central Planning Bureau has compiled for the various economic sectors, of changes in employment levels in the medium term, and also with the Referentieramingen (Reference forecasts) of the Ministry of Education, Culture and Science as regards future flows of students coming from initial education.

The report contains six chapters. Chapter 1 gives a general overview of recent developments, along with forecasts by economic sector, and forecasts by occupation and education at a high level of aggregation. Chapter 2 outlines the most significant developments in the labour market by education and occupation for the years 1995-2000. Chapter 3 presents a more detailed analysis of current questions regarding the market match, followed by the prospects for newcomers on the labour market and the expected risk of problem-areas arising in the labour supply. Chapter 4 discusses the structure of the labour market, by education and occupation. Among other things, this

${ }^{1}$ See A. De Grip, L. Borghans, and E.J.T.A. Willems, Methodology of the ROA information system on occupational groups and types of education, ROA-R-1995/1E, Maastricht, 1995, for an earlier explanation of the ROA methodology in English. 
includes an examination of overlaps in the occupational domains of the various types of education, in order to gain a better understanding of the possible substitution processes in the labour market. This leads to an analysis of the extent to which the expected shifts in the demand for workers from various educational categories result from 1) shifts in the employment per economic sector, 2) from changes in the occupational structure within economic sectors, 3) from shifts in the qualifications which employers seek within occupational classes, and 4) from substitution or crowding-out processes as a result of discrepancies between demand and supply. Chapter 5 provides some further information about the labour market positions of Intermediate Vocational Education and apprenticeship training. The chapter includes a listing of the growth and decline occupations for people with an education at the Intermediate Vocational (IVE) level, including Short IVE and apprenticeship training. This is followed by information on the current and future labour market situation, sensitivity to the business cycle, opportunities to switch, and images of the various fields of education and the problem of the qualitative match between demand and supply on the labour market. Finally, Chapter 6 returns to considering expected labour market developments, from a number of specific perspectives. It begins with the labour market prospects at each educational level, followed by the risk of problems in recruiting labour in the various economic sectors, the labour market prospects of low-skilled or unskilled workers and the labour market prospects for women and members of ethnic minorities.

The following abbreviations and translations have been used in tables referring to levels of education:

English abbreviation

Dutch abbreviation

\begin{tabular}{llc}
\hline LGSE & \multicolumn{2}{l}{ Lower General Secondary EducationMAVO, onderbouw HAVO/VWO } \\
PVE & Preparatory Vocational EducationVBO & \\
SIVE & Short Intermediate Vocational Education & KMBO \\
IVE & Intermediate Vocational EducationMBO/LLW & \\
HGSE & Higher General Secondary Education (SGSE + PUE)HAVO/NWO bovenbouw \\
SGSE & Senior General Secondary Education & HAVO \\
PUE & Pre-University Education VWO & \\
HVE & Higher Vocational EducationHBO & \\
UE & University Education WO WO \\
\hline
\end{tabular}

Many of the courses in Intermediate Vocational Education (IVE) include apprenticeship training in the same subject. However Technical laboratory, Tourism and recreation, Social and cultural and Legal and fiscal have no parallel apprenticeship courses.

ROA's information system project is supervised by Dr. A. De Grip and Dr. L. Borghans. Drs. R.J.P. Dekker, Prof.dr. J.A.M. Heijke, Drs. J. Hoevenberg, Drs. A.G.M. Matheeuwsen, Drs. W. Smits and Drs. E.J.T.A. Willems have also contributed to the current version of the information system and/or this report.

We would like to thank the members of the Supervisory Commission, which consists of the 
following members: Prof. Dr. J.L. Peschar (chairperson; University of Groningen), Drs. J.W. Altena (Statistics Netherlands), Dhr. N.J. Beun (Ministry of Agriculture, Conservation and Fisheries), Dhr. H. Daale (Noordelijke Hogeschool Leeuwarden), Drs. P.C. Van den Dool (Ministry of Education, Culture and Science), Drs. C. Gorter (Ministry of Economic Affairs), Drs. E. Janissen (LDC), Drs. H.J. Roodenburg (Central Planning Bureau), Drs. J.J. Smit (Ministry of Social Affairs and Employment), Drs. M. Wegerif (Central Employment Board), Drs. G.R. De Wit (LDC), Drs. B.T.M. Verlaan (Ministry of Education, Culture and Science) and Drs. J.P. Vosse (Organisation of Strategic Labour Market Research).

Maastricht, October 1995

Prof. Dr. J.A.M. Heijke

Director 


\section{Summary}

Future labour market prospects and labour supply problems

*The number of job openings for newcomers to the labour market in the period 1995-2000 is expected to increase, in comparison with the number of job openings in 1990-1994. This increase is entirely due to increases in the flows of workers leaving the labour market. Total employment is expected to increase by a quarter of a million in the period 19952000, while more than a million workers will leave the labour market. This means, in macro terms, that $80 \%$ of all job openings for newcomers to the labour market will arise because personnel who are leaving have to be replaced.

*In coming years, we expect an average annual growth in the working population of more than $0.8 \%$ per year. This is a slight reduction in comparison with the annual growth of $1 \%$ in the period 1990-1994. Whereas in the first half of the nineties just $2.2 \%$ of workers left the labour market per annum, in the period 1995-2000 the average annual rate of departure is expected to be $3.3 \%$. Moreover, the average annual flow of school-leavers entering the labour market, as a percentage of the existing labour force, is expected to fall from $3.7 \%$ to $3.4 \%$. The improvement in replacement demand and the declining flows of schoolleavers entering the labour market will mean that the labour market prospects for schoolleavers will generally be somewhat better in the coming years.

*There are fields of study with good and bad labour market prospects at every educational level (except for workers without any educational qualification). In general, the prospects for people with lower and intermediate level education are worse than for those with higher education. Especially at Higher Vocational Education (HVE) and University Education (UE) level, there are many types of education with good labour market prospects. A detailed overview of the labour market prospects per type of education is given in Section 3.2 of this report, and in Table 3.30 of the Statistical Appendix.

*The sectors which are expected to face recruitment problems as regards many fields of study in higher education are 'Other commercial services', 'Civil service, police, defense and education' and 'Non-commercial services'. For the other economic sectors, the expected recruitment problems relate largely to a number of technical fields of study. This includes not only technically-trained tertiary graduates in the fields of Electronic and information technology, Construction and civil engineering, and Transport and harbour, but also two types of education at the Intermediate Vocational Education (IVE) or apprenticeship level: Precision engineering and Medical laboratory.

*The expected developments in employment levels at the lower end of the labour market are far from promising. The demand for workers who do not have even a basic qualification at the level of initial apprenticeship will fall strongly. This fall is largely due to an upgrading of the qualification prerequisites in the occupations in which those with lower levels of education are employed, but is exacerbated by the fact that the occupations in which less educated 
people work account for a declining share of employment, and by a crowding-out process as people with intermediate-level education enter these occupations. However this declining demand is to some extent counter-balanced by a decline in the numbers of school-leavers who do not have even a basic qualification. This decline will prevent any further deterioration in the labour market position of these types of education. There are some types of education at the Preparatory Vocational Education (PVE) level with good or reasonable labour market prospects, although for the great majority of the Preparatory Vocational Education courses the prospects are moderate or bad. Thus any further reduction in the number of students entering the labour market without a basic qualification would mean not only that more school-leavers would have an education which measured up to the qualification requirements which are now being set in the labour market, but also that the position of those without such a training would improve, so that these school-leavers could also find a suitable place in the labour market.

${ }^{*}$ The overall employment share of Intermediate Vocational Education and apprenticeship training is not expected to increase any further in the coming years, but there are large differences between the various types of education at this level. Positive effects on employment levels derive mainly from the progressive upgrading of skilled labouring work. A qualification at the Intermediate Vocational Education level is increasingly becoming the minimum requirement for skilled labourers. Thus Intermediate Vocational Education has a crucial role in maintaining the productivity of the Dutch labour force at the required level particularly in the light of the international competitive position of the Dutch economy.

*Employment for a number of categories of higher education is expected to increase strongly in the coming years. This is due to three factors. In the first place, those with higher education find employment in occupations which will enjoy strong employment growth in the coming years. In the second place, education at the Higher Vocational Education or University Education level is increasingly being asked for in these occupations. In the third place, those with higher education profit from the presence of supply shortages for other types of (higher) education. Especially in the fields of tertiary education in information science, economics, management and engineering, the expected expansion demand is high or very high. In contrast, the job openings for those educated in vetinary and medical sciences and dentistry, in theology and as teachers is expected to consist mainly of a very high replacement demand.

Women

*Although there are substantial differences between men's and women's educational choices, the average labour market prospects for women are almost as good as those for men. There is a small difference because women are more strongly represented in types of education delivering relatively high numbers of school-leavers to the labour market. The difference is greater if one looks at the occupations in which women work. In fact women are clearly under-represented in a number of strongly growing occupational classes.

Members of ethnic minorities 
*Workers from ethnic minorities have, on average, poorer educational backgrounds and clearly less favourable labour market prospect than the average Dutch labour force. But there is a big difference between members of ethnic minorities from the countries covered by the 'Promotion of Balanced Employment Participation by Members of Ethnic Minorities Act' (Wet Bevordering Evenredige Arbeidsdeelname Allochtonen, WBEAA) ${ }^{2}$ and members of other ethnic minorities, most of whom come from Western countries or from Eastern Europe. Turkish and Moroccan immigrants, who often have no education or education at only a low level, face especially unfavourable labour market prospects. Therefore it is very important to reduce the proportion of young people from ethnic minorities who drop out of school in the phase at which they might be gaining qualifications for employment.

The labour market prospects of ethnic minorities from the Southern countries of the European Union are no better than those from the target countries of the Ethnic Minorities Act. In contrast, the prospects for minority groups from the other Member States of the European Union, the United States and Eastern Europe are actually better than the average prospects of Dutch workers. This is probably due to a 'pull effect': in the occupational classes, and for the types of education, with shortages, many people are recruited abroad, and these apparently come mainly from the United States and Eastern Europe.

Sensitivity to business cycle fluctuations

*Employment levels for the technical occupations and types of education, in particular, are highly sensitive to the state of the business cycle. This is especially true for the types of education at the level of Preparatory and Intermediate Vocational Education. At Higher Vocational Education and University Education level, the only fields for which employment is highly sensitive to the business cycle are electrical engineering and information technology.

*There are striking differences between the cyclical sensitivity of the flows entering one of the diverse types of apprenticeship and the cyclical sensitivity of employment levels for those who have completed the corresponding type of education. Thus, the numbers entering the various technical apprenticeships exhibit very low to average sensitivity to the state of the business cycle, despite the high cyclical sensitivity of employment in these fields. For these types of education it has apparently been possible to achieve reasonably stable apprentice numbers, despite highly changeable conditions. This is very important, because the flows entering the apprenticeship system are the qualified tradesmen and skilled labourers of a few years later. By that time, economic decline may already have given way to an economic recovery. In contrast, the sensitivity of most non-technical types of education to the state of the business cycle is average. In fact the flows of apprentices entering the ECABO types of education (i.e., administration) are highly sensitive to the state of the business cycle. Table 5.4 provides a complete overview of the sensitivity of

\footnotetext{
${ }^{2}$ The countries are Aruba, the Dutch Antilles, Ethiopia, Iraq, Iran, the former Yugoslavia, Morocco, Somalia, Surinam, Turkey and Vietnam.
} 
apprenticeship intakes to business cycle fluctuations.

\section{Opportunities to switch to other occupations}

*Although the specific nature of technical types of education inevitably means that each course is strongly focused on a specific technical occupation, those with a technical education enjoy opportunities to switch to other occupations which are generally quite as good as those for other types of education. This labour market flexibility arises because most of them work in non-technical fields. Especially in these occupations, people with technical education in various fields seem to be substituted for one another quite readily, and they also compete with those with other types of education. This alternative domain is very valuable for those with a technical education, in the light of the high sensitivity of employment in many technical occupations to the state of the business cycle.

${ }^{*}$ For types of education which are specifically focused on occupations in the non-commercial services sector (teachers, medical personnel etc.), the opportunities to switch to other economic sub-sectors and occupations are, in practice, generally very low. This means that people with this educational background are almost entirely dependent on changes in employment levels in the public sector. Marked changes in employment trends in the public sector will therefore have a large effect on workers with these types of education. In contrast to most technical types of education, these types of education do not have any extensive alternative domain, which would enable them to absorb such breaks in employment trends.

\section{Affinity between levels of education}

*Many types of education exhibit clear affinities, in the labour market, with some other types of education (see figure 4.1). This leads to competition between them, but it also increases the flexibility of the labour market very much. For the agricultural and technical types of education, affinities between occupational domains, across educational levels, are particularly strong between the University Education and Higher Vocational Education levels, and between the Intermediate Vocational Education and Preparatory Vocational Education levels. This contrasts with the clear demarcation between occupational domains at the Higher Vocational Education and Intermediate Vocational Education levels. However, for a number of types of education which are directed at the noncommercial services sector, there is a high degree of affinity between the occupational domains at Intermediate Vocational Education and Higher Vocational Education levels.

${ }^{*}$ One cannot take the affinity between the occupational domains of University Education and Higher Vocational Education courses, in itself, as evidence that the distinction between University Education and Higher Vocational Education is fading. The occupational domain which is shared by two different levels is generally not a part of the principal, and specific, occupational domain of the university course in question. Thus it is still possible to identify specific university-level occupations, even though many university graduates work in other jobs, alongside graduates from Higher Vocational Education. 
$\ldots \ldots$ 


\section{An overview of the labour market}

Growth in the Dutch economy accelerated last year, but despite the economic recovery employment levels remained static. However this year employment growth over a broad front is once again evident. This growth is expected to decline somewhat from 1996. However for this report, which focuses on the prospects which occupations and types of education face on the labour market, economic changes due to the business cycle are less important than medium-term economic developments. The time horizon for the report is five years. This chapter, which gives an overall picture of future developments in the labour market, will first provide a general description of the expected developments in the labour market. This will be followed by discussions of employment prospects by economic sector, by occupational sector and by educational category, at a relatively high level of aggregation. Expected changes in employment levels by occupation and by type of education will be discussed in more detail in the following chapters. This chapter will close with a more detailed examination of some specific developments in the labour market.

\section{Expected changes in the labour market}

The forecasts of employment levels in this report are based, at the level of economic sectors, on forecasts made by the Dutch Central Planning Bureau (CPB). The forecasts for 1995 and 1996 are the same as the short-term forecasts given in the Central Economic Plan of 1995. According to these forecasts, the economic upturn of 1994 will continue more strongly in 1995, and weaken somewhat in 1996. The gross domestic product is expected to increase by $3.25 \%$ in 1995 and by $2.75 \%$ in 1996. The forecasts for 1997 and 1998 are based on the medium-term forecasts from 1994. ${ }^{3}$ Since the current economic upturn may be only temporary, we have chosen the more conservative scenario from these forecasts, to be on the safe side. This scenario assumes a growth in the relevant world trade flows of $4.5 \%$ per year, and infers national economic growth averaging $2 \%$ per year. ${ }^{4}$ For 1999 and 2000 , the forecasts are based on the assumption that the employment trends predicted by the CPB for 1997 and 1998 will continue.

For 1995-2000, employment volume, in 'labour years' (equivalent to 12 month's full-time work) is expected to grow by almost $0.6 \%$ per year. But because of the steady increase in part-time work, which is leading to a continuous rise in the ratio between the number of workers and the number of labour years, the annual rise in the number of people employed (the 'employment level') is higher. The average annual growth in the working population is expected to be more than $0.8 \%$ per year in the coming years (see Table 1.1). This growth rate is almost the same as the average growth in employment in the first half of the nineties. ${ }^{5}$ However this included a period of strong growth in employment in the years 1990 to 1992 and a strong decline in employment growth in 1993 and 1994. In accordance with the forecasts of economic growth named above, and bearing in mind that

${ }^{3}$ CPB, Centraal Economisch Plan 1994 (Central economic plan 1994), Den Haag, 1994.

\footnotetext{
${ }^{4}$ The forecasts for 1997 and 1998 do not make any allowance for the economic effects of the inter-party agreement on which the current coalition government is based. The forecasts for 1995 and 1996 do take this agreement into account.

${ }^{5}$ The employment growth of 1.0\% per year in the period 1990-1994, in Table 1.1, is based on the Labour Force Survey (Enquête Beroepsbevolking, or EBB) of Statistics Netherlands. Because of differences in the definition of the labour force, for example as regards people more than 65 years old and international commuters, these figures do not correspond exactly with the growth figures put out by the CPB. According to the figures of the CPB (1995), which are based on the national budget, employment grew by an average of $0.8 \%$ per year in the period 1990-1994.
} 
there is some delay between economic growth and its effects on employment levels, the strongest growth in employment is expected in 1995 and 1996, after which employment growth is expected to decline again to some extent.

Table 1.1

Labour market developments in 1990-1994, and forecasts for 1995-2000

\begin{tabular}{lll}
\hline & \multicolumn{1}{c}{$1990-1994$} & $1995-2000$ \\
& $\%$ & $\%$ \\
& & 0.8 \\
& 1.0 & 3.3 \\
Increase in employment (av. annual change) & 2.2 & 4.2 \\
Flows of workers leaving the market & 3.2 & 3.4 \\
Job openings & 3.7 & \\
Flows of school-leavers entering the market & & \\
\end{tabular}

Averaged annual flows, as percentages of the labour force in the previous year Source: $\mathrm{CBS} / \mathrm{CPB} / \mathrm{ROA}$

Despite the limited growth in employment over the five-year forecast period, the labour market prospects for school-leavers in that period are still expected to improve somewhat. These improved prospects are due mainly to demographic developments, which will lead to an increase in the need for new workers to replace departing workers (replacement demand) and to some decrease in the flows of school-leavers entering the market (see Table 1.1). Whereas just $2.2 \%$ of workers left the labour market each year in the first half of the nineties, for 1995-2000 the average annual flows of workers leaving the market are expected to reach 3.3\%. In comparison with the 1990-1994 period, this means that the number of positions falling vacant will increase by an average of 60,000 per year. In short, between 1995 and the year 2000, employment is expected to increase by 250,000 persons, while more than a million workers will leave the labour market. In macro terms, this means that $80 \%$ of all job openings arise because personnel who are leaving have to be replaced. Because a vacant position is not always filled by a newcomers with the same educational background, one cannot simply translate flows of workers leaving the market into replacement demand for workers with the same type of education. Some of the outflow from the market will also result in expansion demand for other types of education.

In addition to this increase in the flows leaving the labour market, school-leavers can be expected to benefit more than other groups from the predicted growth in employment. This is because a relatively large proportion of the increase in the labour supply consists of immigrants and people reentering the labour market after a period of work disability or of temporary withdrawal while raising young children. As a whole, these groups have a weaker position in the labour market. Moreover, the average annual flows of school-leavers entering the labour market will decline from $3.7 \%$ to $3.4 \%$ of the labour force. ${ }^{6}$ But good labour market prospects for school-leavers do not automatically mean that employers will face recruitment problems. They can, for example, respond to this situation by slowing the outflow of older workers or by drawing on the reservoir of long-term

\footnotetext{
${ }^{6}$ An allowance has also been made here for the ending of compulsory military service, which will produce an one-off surge in the supply of labour from school-leavers.
} 
unemployed, ${ }^{7}$ or on the labour of the groups with a weaker labour market position which were mentioned above.

\section{Employment by economic sector}

Table 1.2 gives a picture of the expected expansion demand in the period 1995-2000, broken down by economic sectors. Employment is expected to increase in 8 of the 13 economic sectors which are distinguished here, with the highest growth expected in the non-commercial services sector. It is striking that the growth in this sector is expected to be even higher than in recent years. Expansion demand for other commercial services, the chemical industry and in commerce is expected to be almost as high. Growth in the latter two sectors is clearly better than in the period 1990-1994, and in the case of the chemical industry there is even a turnaround from declining employment to employment growth.

On the other hand, five sectors will suffer declining employment. The largest decrease in employment, in proportional terms, will be in the agricultural sector. This decline is a continuation of the trend in the 1990-1994 period. Declining employment levels are also expected in the food and beverage industry, financial services and the public sector (the civil service, police, defense and education workers). For the first two of these, this decline is the continuation of previous trends, but in the public sector the upward trend in employment levels in the first half of the nineties will be reversed.

Table 1.2

Changes in the number of workers per economic sector, 1990-1994, and expansion demand 1995-2000 (average percentage growth per year)

\begin{tabular}{lccc} 
Economic sector & $\begin{array}{l}\text { number of workers } \\
\text { (average '93/'94) }\end{array}$ & $\begin{array}{c}1990-1994 \\
\%\end{array}$ & $\begin{array}{l}1995-2000 \\
\%\end{array}$ \\
\hline & & & -2.9 \\
Agriculture and fisheries & 231,500 & -3.6 & -0.6 \\
Food and beverage industry & 157,500 & -1.7 & -0.3 \\
Other industry & 242,500 & -2.7 & 1.8 \\
Chemicals & 125,000 & -2.2 & 0.5 \\
Metal and electrical industries & 491,000 & -2.8 & 0.4 \\
Energy & 65,000 & 1.3 & 0.6 \\
Construction & 428,500 & -0.3 & 1.8 \\
Commerce & 822,000 & 0.7 & 0.7 \\
Transport, storage and communication & 373,500 & 1.7 & 1.9 \\
Other commercial services & 756,500 & 2.9 & -0.6 \\
Financial services & 207,500 & -1.1 & 2.0 \\
Non-commercial services & 937,000 & 1.4 & -0.9 \\
Civil service, police, defense and education & 609,500 & 1.0 & 0.8 \\
& & & \\
Total & $5,885,500$ & 1.0 & \\
\end{tabular}

Source: $\mathrm{CBS} / \mathrm{CPB} / \mathrm{ROA}$

\footnotetext{
${ }^{7}$ In determining the labour market prospects of school-leavers, it is assumed that job-seekers who have been out of work for longer than a year do not compete with school-leavers.
} 


\section{Employment by occupational sector}

Changes in employment levels in the various economic sectors have a large influence on the expansion demand in occupations. The expansion demand in particular occupations is also influenced by shifts in the occupational structure within the various economic sectors. Table 1.3 gives an overview of the expected change in employment levels per occupational sector. However it must be remembered that the occupational sectors are quite heterogeneous. In chapter 2 we will see that within most occupational sectors it is mainly the higher occupations which are expected to grow strongly, while employment for many lower occupations is expected to decrease. The medical and paramedical occupations will enjoy the highest expansion demand. As in the first half of the nineties, relatively high expansion demand is also expected for the cultural and socio-cultural occupations. Employment increases are also expected for the commercial and administrative, and educational, occupations, although the employment growth for the latter is very much lower than the growth in recent years. Finally, it is striking that a positive reversal in the employment level trends in the first half of the nineties is expected for the technical and industrial occupations.

Employment in four occupational sectors is expected to decline in the coming years. The biggest fall will be in the agricultural occupations, which has been the case for many years, but the public security and safety occupations are also expected to suffer a relatively large decline in employment, largely as a result of declining employment in the defence sector. 
Table 1.3

Changes in the numbers of workers per occupational sector 1990-1994, and expansion demand 1995-2000 (average percentage growth per year)

\begin{tabular}{|c|c|c|c|}
\hline Occupational sector & $\begin{array}{l}\text { number of workers } \\
\text { (av. '93/'94) }\end{array}$ & $\begin{array}{l}1990-1994 \\
\%\end{array}$ & ${ }^{1995-2000}$ \\
\hline
\end{tabular}

Educational occupations

Cultural occupations

Agricultural occupations

Technical and industrial occupations

Transport occupations

Medical and paramedical occupations

Commercial and administrative occupations

Socio-cultural occupations

Hotel, catering and service occupations

Public security and safety occupations

Total (incl. occupation not known)

$\begin{array}{crr}321,500 & 2.9 & 0.6 \\ 80,500 & 1.7 & 1.9 \\ 247,500 & -4.5 & -2.5 \\ 1,577,000 & -1.6 & 0.3 \\ 335,000 & 1.2 & 0.3 \\ 402,500 & 1.0 & 2.3 \\ 1,923,000 & 1.3 & 1.2 \\ 186,000 & 3.0 & 1.9 \\ 494,000 & 1.0 & -0.5 \\ 97,000 & 0.8 & -1.6 \\ 5,885,500 & 1.0 & 0.8\end{array}$

Source: CBS/ROA

Table 1.4

Changes in the number of workers per educational category 1992-1994, and expansion demand 1995-2000 (average percentage growth per year)

\begin{tabular}{lccc} 
Educational category & $\begin{array}{c}\text { number of workers } \\
\text { (av. '93/'94) }\end{array}$ & $\begin{array}{c}1992-1994 \\
\%\end{array}$ & $\begin{array}{c}1995-2000 \\
\%\end{array}$ \\
\hline & & & \\
Primary Education & 508,000 & -5.2 & -2.8 \\
Lower General Secondary Education & 408,500 & 0.7 & -0.9 \\
PVE, Technical and agricultural & 560,000 & -3.7 & -1.2 \\
PVE, Commerce and administration & 93,000 & -7.3 & -0.9 \\
PVE, Personal services & 208,500 & -0.6 & -0.3 \\
Higher General Secondary Education & 294,000 & 0.9 & 1.3 \\
IVE, Technical and agricultural & 872,000 & 1.7 & 0.8 \\
IVE, Nursing and laboratory & 211,500 & 1.5 & 1.7 \\
IVE, Commerce and administration & 595,500 & 2.4 & 0.9 \\
IVE, Personal services & 400,500 & 2.4 & 1.2 \\
HVE, Technical and agricultural & 175,500 & 1.9 & 3.5 \\
HVE, Medical, paramedical and laboratory & 104,500 & 1.7 & 3.1 \\
HVE, Commerce and administration & 140,000 & 6.4 & 3.8 \\
HVE, Social and educational & 434,000 & 2.2 & 1.8 \\
UE, Technical and agricultural & 90,000 & 4.8 & 4.1 \\
UE, Medical & 57,000 & 5.0 & 3.1 \\
UE, Economic and legal & 112,500 & 0.8 & 4.0 \\
UE, Social sciences and arts & 136,500 & 1.0 & 3.2 \\
Total (incl. education not known) & & & \\
& $5,885,500$ & 0.4 & 0.8
\end{tabular}

Source: CBS/ROA

Employment by educational category 
Table 1.4 gives an overview of the expected expansion demand by educational category. However it is important to note that the predicted expansion demand is based on developments on the demand side of the labour market. The actual change in employment levels may differ from the expansion demand because of discrepancies between demand and supply. ${ }^{8}$ From the table it is clear that the highest growth rates, as in past years, ${ }^{9}$ will be for those with higher education. The expansion demand will be greatest for medical, paramedical and laboratory education, technical and agricultural education, and economic education at both Higher Vocational Education and university levels.

Although there is a relatively high expansion demand for commerce and administration education at the Higher Vocational Education level, this is much less than the employment growth for this educational category in the first half of the nineties. For economic and legal education at the university level, the expansion demand in the second half of the nineties is expected to be at a higher level than the growth in employment in recent years. The same applies for agricultural and for medical and paramedical and laboratory education at the Higher Vocational Education level.

Figure 1.1

Labour market prospects for school-leavers, by educational category, in the year 2000

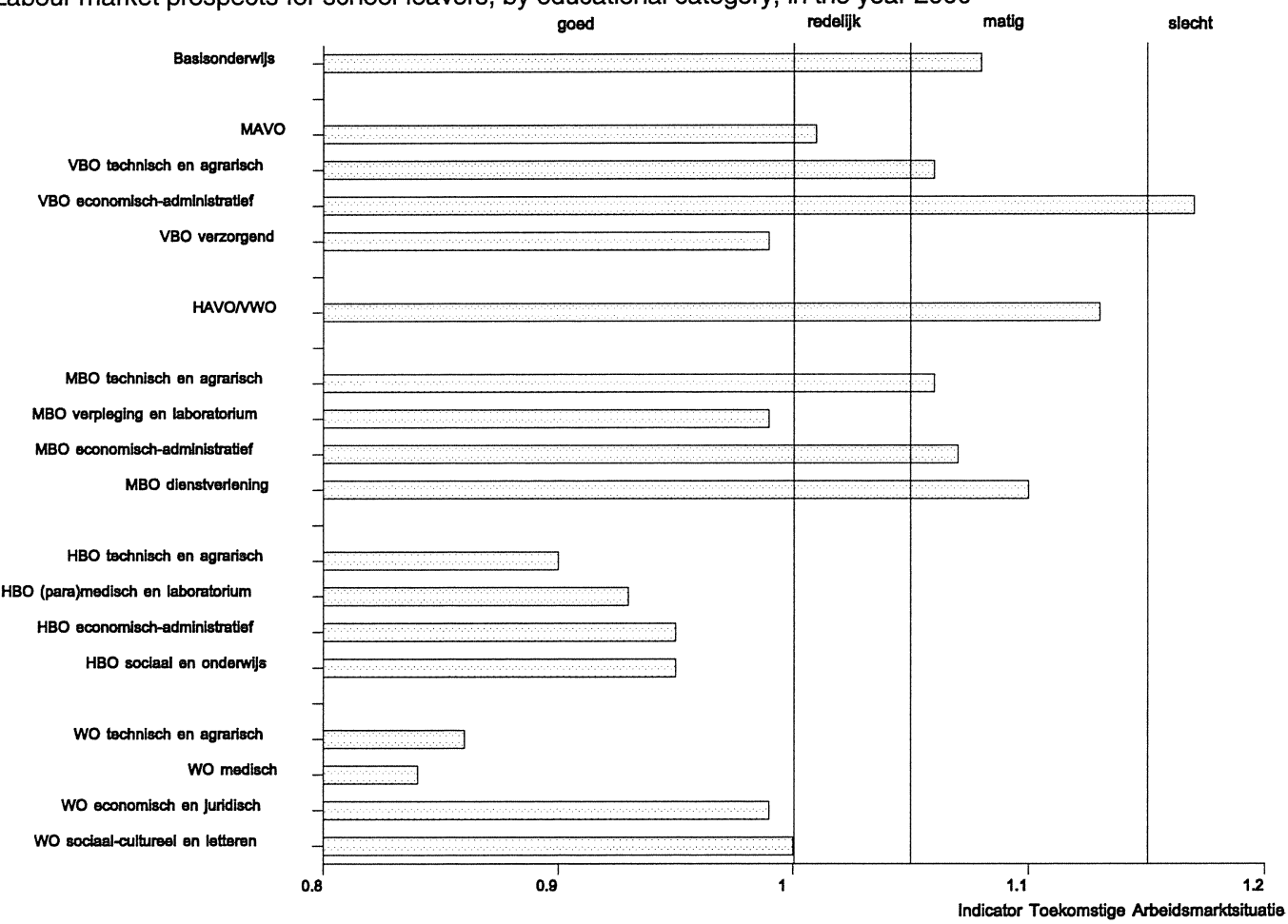

The predicted expansion demand for those with intermediate-level education is clearly lower than

\footnotetext{
${ }^{8}$ See section 2.1 .

${ }^{9}$ Data on the change in employment levels disaggregated for the types of education distinguished in this report is only available for the years 1992-1994.
} 
for those with higher education. At the Intermediate Vocational Education level the highest expansion demand is expected for Nursing and laboratory education. For those with lower education (at the Preparatory Vocational Education and LGSE level) and those with only primary education, falling demand is expected across the board. With the exception of those with Lower General Secondary Education, this corresponds to employment level trends in the previous period.

Figure 1.1 gives a broad picture of the labour market prospects of newcomers to the labour market. The table shows that the labour market prospects for newcomers with higher education will in general improve. Of those with intermediate and lower-level education, only those with Medical or Personal services training will enjoy good prospects. In fact, at the lower end of the labour market the prospects are predominantly moderate to bad. If a particular type of education has good labour market prospects, it may be difficult for employers to recruit school-leavers with that type of education. Thus there is a high risk of recruitment problems for those types of education with good labour market prospects. It follows that future problem areas in the labour supply will arise mainly in relation to those with higher education, especially in the technical, agricultural, economic and medical fields. Chapter 3 will give a more detailed picture of the labour market prospects and of the expected recruitment problems.

\section{The disappearance of low-skilled work}

As Table 1.4 showed, expectations as regards changes in employment levels on the lower end of the labour market are hardly favourable. The total demand for workers without even a basic qualification at at least the level of an initial apprenticeship, over the coming five years, is expected to decline by more than 127,000 . The fall in the demand for those with lower levels of education is partly due to shifts in the occupational structure of employment, but is largely due to shifts in the educational background which is demanded of workers in the various occupations.

Fortunately this declining demand is partly counterbalanced by strongly declining flows of people entering the market with only lower-level education. For example, the annual flows of school-leavers entering the market without even a basic qualification at the level of an initial apprenticeship, in the period 1995-2000, is expected to be more than 20,000 less than it was in the first half of the nineties. Less and less people are doing Preparatory Vocational Education courses, and most of those who gain a Preparatory Vocational Education qualification go on to Intermediate Vocational Education courses, or to an apprenticeship. This prevents the labour market position of those with Preparatory Vocational Education becoming even worse, and even at the Preparatory Vocational Education level there are some types of education with good or reasonable prospects. However, for most types of Preparatory Vocational Education the prospects are moderate or bad.

Increasing employment flexibility

Since the seventies, a gradual shift in the nature of workers' employment contracts has been taking place. First of all, there has been an enormous growth in part-time work, so that the Netherlands 
now has one of the highest rates of part-time work in the European Union. ${ }^{10}$ On the one hand, this could be seen as a positive development, because it means that more and more people are able to combine paid work with caring for their children. On the other hand, it might also be an indication of a slack labour market. In the latter case, people are working part-time involuntarily because they have not been able to find a full-time job. There has also been an ongoing increase in the use of flexible labour contracts, in the form of temporary work, 'temping' through employment agencies, seasonal work, working at home, on-call work etc. This is often a negative development from the employees' point of view.

Table 1.5

Flexible work and part-time work per occupational sector, 1994

Occupational sector

\begin{tabular}{ccc} 
flexible work* & \multicolumn{2}{c}{ part-time work } \\
$\%$ characterization & $\%$ characterization
\end{tabular}

\begin{tabular}{llllll}
\hline & & & & \\
Educational occupations & 4 & low & 32 & average \\
Cultural occupations & 3 & low & 25 & average \\
Agricultural occupations & 4 & low & 17 & average \\
Technical and industrial occupations & 1 & low & 6 & low \\
Transport occupations & 7 & average & 12 & high \\
Medical and paramedical occupations & 6 & average & 47 & high \\
Commercial and administrative occupations & 4 & low & 26 & average \\
Socio-cultural occupations & 2 & low & 39 & high \\
Hotel, catering and service occupations & 10 & high & 55 & very high \\
Public security and safety occupations & 0 & very low & 4 & very low \\
& & & & 25 &
\end{tabular}

Source: CBS/ROA

* Because the CBS does not record any occupational group for those workers with contracts covering less than six months, and without the prospect of permanent employment, this category of flexible jobs are not included here.

Part-time work is almost entirely women's work, and flexible employment relationships of all sorts are concentrated largely among women and young people. ${ }^{11}$ Table 1.5 shows that the percentage of part-timers is very high in the hotel, catering and service occupations. In this occupational sector, which employs many women, more than half of the employees work part-time. Part-time work is especially common for geriatric help and kindergarten staff, community workers and probation officers, and porters, cleaners and domestics.

The hotel, catering and service occupations also have the highest incidence of flexible employment contracts: about $10 \%$ of the employees work under such a contract. ${ }^{12}$ For the occupational classes

${ }^{10} \mathrm{~J}$. Hoevenberg and A. de Grip, Indicators of Occupational Employment in the European Union, ROA-R-1994/3E, Maastricht, 1993.

${ }^{11}$ Lei Delsen, Atypical Employment: an International Perspective, Wolters-Noordhoff, Groningen, 1995.

${ }^{12}$ This percentage would be even higher if those who work less than 12 hours per week were also included. 
of cooks, waiters and kitchen workers and geriatric help and kindergarten staff, in particular, the numbers of workers with a flexible contract reach very high levels.

The number of part-time workers is also high in other occupational sectors in which many women are employed. This refers mainly to the medical and paramedical, and the socio-cultural, occupations. Especially among doctors', dentists' and vetinary assistants, and in the various nursing and health care occupations, part-time work is very common. For the physiotherapists and occupational therapists, in particular, the number of workers with a flexible employment contract is very high.

This picture is reflected in the educational background of those working part-time. Thus the rate of part-time work is very high for those trained in the fields of personal services and nursing, or as medical assistants, at the levels of Preparatory Vocational Education or Intermediate Vocational Education and apprenticeship. Flexible employment contracts, in contrast, are particularly common for those with Higher General Secondary Education (without any completed vocational education) or with Preparatory Vocational Education in Community care, hotel and catering.

\section{Some specific groups}

Data from various sources shows that some particular groups of workers often have a weaker labour market position. Therefore the labour supply authorities regard most of these groups as specific target groups under their policies for both job placement and further training. The most important groups which often have weak labour market positions (in addition to those without educational qualifications, young people and the long-term unemployed) are women and members of ethnic minorities.

Table 1.6 shows that the unemployment rate for these groups is clearly higher than the average unemployment rate for the whole labour force. Unemployment is highest among members of ethnic minorities, with rates as high as $31 \%$ for workers with Turkish and Moroccan backgrounds. For Turks this percentage is somewhat higher than in past years, while unemployment among Moroccans in the Netherlands has in fact fallen. Unemployment is also high among ethnic minorities from the other Mediterranean countries. In 1994, unemployment among this group reached $20 \%$. This rate has in fact risen dramatically, compared with the previous years, when unemployment among members of ethnic minorities from around the Mediterranean (excluding Morocco and Turkey) never exceeded $13 \%$. The group consisting of Indonesians and IndonesianNetherlanders is the only ethnic minority of any size for which the unemployment rate is the same as for the native Dutch population. 


\begin{tabular}{lcc}
\hline & $\%$ & \\
& & \\
& 17 & 13.3 \\
No qualifications & 11.4 & \\
Young people (<25 years) & 20 & \\
Women & & 31 \\
Members of ethnic minorities & 31 \\
Of which: & 20 \\
$\quad$ Turks & 13 \\
$\quad$ Moroccans & 21 \\
$\quad$ Other Mediterranean peoples & 21 \\
$\quad$ Europeans excl. Mediterraneans & 9 \\
$\quad$ Surinamese & & 26 \\
$\quad$ Antillians & & \\
$\quad$ Indonesians/Indonesian-Netherlanders & & \\
$\quad$ Other & 8.5 & \\
Total labour force & & \\
&
\end{tabular}

\section{Source: CBS}

* the unemployed labour force

Table 1.7 gives some insight into the occupational sectors in which women and workers from ethnic minorities work. ${ }^{13}$ Women have a higher than average probability of working in medical and paramedical occupations, in hotel, catering and service occupations and in socio-cultural occupations. Table 1.5 shows that medical and paramedical occupations and the hotel, catering and service occupations are also the occupational segments with the greatest percentages of flexible and part-time contracts. Moreover, employment in the hotel, catering and service occupations will fall in the coming years. Members of ethnic minorities are also relatively overrepresented in hotel, catering and service occupations. Because these are occupations with falling employment levels, the labour market position of members of ethnic minorities may deteriorate further in comparison with the native Dutch population.

If we consider the occupational classes in which many people from these groups are employed, we find that women comprise more than three-quarters of the workers in nine medical, personal services and administrative occupational classes, in occupations such as doctors', dentists' and vetinary assistants, secretaries and typists, nursing staff and geriatric help and kindergarten staff. Members of ethnic minorities seem to be particularly often found in some low-skilled technical occupations and as freight handlers and packers. Some specific internationally oriented occupations, such as translators and other literary professions, visual and performing artists, military professionals and, to a somewhat lesser extent journalists and announcers, also attract relatively many foreigners. But in these cases these are foreigners from the other Members States of the European Union or from the United States.

\footnotetext{
${ }^{13}$ Chapter 6 will examine the position of these specific groups on the labour market in more detail.
} 
Table 1.7

Characteristics of workers in each occupational sector, 1994

$\begin{array}{lll}\text { Occupational sector } & \text { women } & \text { ethnic minorities } \\ & \% \text { characterization } & \% \text { characterization }\end{array}$

\begin{tabular}{lrllrl} 
Educational occupations & 46 & average & 5 & low \\
Cultural occupations & 34 & average & 10 & average \\
Agricultural occupations & 19 & low & 2 & low \\
Technical and industrial occupations & 7 & very low & 7 & average \\
Transport occupations & 13 & low & 8 & average \\
Medical and paramedical occupations & 75 & high & 5 & low \\
Commercial and administrative occupations & 48 & average & 6 & average \\
Socio-cultural occupations & 56 & high & 2 & low \\
Hotel, catering and service occupations & 69 & high & 12 & high \\
Public security and safety occupations & 7 & very low & 8 & average \\
& & & & \\
Total & 37 & & & 8 \\
\hline
\end{tabular}

Source: CBS/ROA

Table 1.8 gives a picture of the educational background of these groups. It shows even more clearly than the list of occupational sectors in which these groups work that the various target groups have an entirely different labour market position. For example, the percentages of women are high or very high for the personal services and medical types of education at the Preparatory Vocational Education, Intermediate Vocational Education and Higher Vocational Education levels, for commercial and administrative education at Preparatory Vocational Education level, and for the social and educational types of education at the Higher Vocational Education level. The types of Higher Vocational Education in which women are relatively well represented have good labour market prospects, and the same applies for PVE, Personal services. But the commercial and administrative types of education at the Preparatory Vocational Education level offer bad employment prospects. It is also striking that women are very much under-represented in a number of types of education with very favourable labour market prospects (e.g., the technical and agricultural, and economic, types of education at Higher Vocational Education and University Education levels).

In contrast, the members of ethnic minorities are over-represented at the lower end of the labour market, among those without educational qualifications or with only Lower General Secondary Education. This partly explains the high unemployment rate for members of ethnic minorities, although the unemployment rate for Dutch natives with lower-level education is much lower than the rate for members of ethnic minorities. Turks and Moroccans are the most heavily over-represented among those without any qualifications. For workers from these minority groups, the proportion with no educational qualifications is about six times the rate for the total labour force. On the other hand, there are some types of higher education with relatively many members of ethnic minorities, but these are often workers from northern EU countries and the United States. The United States, in particular, supplies relatively many specialized workers with higher education, such as information scientists, technicians and physicians, and also theologians and workers with a university education in 'Arts' (i.e., humanities). A number of highly-educated information scientists and technicians also 
come from Eastern Europe. 
Table 1.8

Characteristics of workers by educational category, 1994

Educational category

women

ethnic minorities

$\%$ characterization \% characterization

Primary Education

Lower General Secondary Education

PVE, Technical and agricultural

PVE, Commerce and administration

PVE, Personal services

Higher General Secondary Education

IVE, Technical and agricultural

IVE, Nursing and laboratory

IVE, Commerce and administration

IVE, Personal services

HVE, Technical and agricultural

HVE, Medical, paramedical and laboratory

HVE, Commerce and administration

HVE, Social and educational

UE, Technical and agricultural

UE, Medical

UE, Economic and legal

UE, Social sciences and Arts

Total (incl. education not known)

average
average
very low
high
very high
average
very low
very high
average
high
very low
high
low
high
very low
average
low
average

average

37

very high
high
low
average
low
high
low
low
low
low
average
low
very low
average
average
high
average
average

8

Source: CBS/ROA 


\section{Developments on the labour market, 1995-2000}

\subsection{Introduction}

An approach based on flow volumes has been chosen for the labour market forecasts in ROA's information system for education and the labour market. Under this approach, forecasts are made of the flows entering and leaving the labour market in a particular future period. This approach has the advantage of showing the processes that are important for the development of demand and supply in the labour market. The forecasts are compiled for a total of 93 occupational classes and 79 types of education, over the full width of the labour market. ${ }^{14}$

Figure 2.1 gives a schematic overview of the forecasting model used in the information system for education and the labour market. ${ }^{15}$ One flow volume which is important for the demand side of the labour market is the expansion demand, which reflects the movement in employment levels in a particular occupational class or for a particular type of education. The forecasts of expansion demand are based on the employment level forecasts for economic sectors which are produced by the Dutch Central Planning Bureau (see Table 1.2). Because particular occupational classes within an economic sector grow more rapidly than others, ROA translates these changes in the economic sectors into the expansion demand per occupational class. Then the implications of the predicted growth in the various occupational classes for the expansion demand for each type of education are determined. An allowance is made at this point for any shifts which may be occurring in the educational structure of occupational classes. The expansion demand per type of education refers to the number of people with a particular educational background that employers would like to be able to employ. The actual change in employment levels per type of education will generally differ from this because changes on the supply side affect relative scarcities and lead to substitution processes.

Demand on the labour market consists not only of expansion demand, but also of replacement demand, which arises when workers retire, leave the labour force under the early retirement scheme or due to work disability, withdraw from the labour market temporarily, or switch to another occupation etc. However replacement demand only arises if the departure of an employee actually leads to a vacancy for a new entrant. If the departure of a worker is taken as an opportunity to cut employment levels, no replacement demand results. These flows out of the labour market are in fact irrelevant for newcomers. Thus only part of the flows leaving the market generate replacement demand. Moreover, there is an important difference between the replacement demand per occupational class and per type of education, because occupational mobility has an influence on the replacement demand per occupational class, but not on the replacement demand per type of education. Switching occupations has no effect on the educational structure of employment.

${ }^{14}$ In the previous report 49 types of education were distinguished. The difference arises because, at all levels of education, the technical and commercial and administrative types of education have been further disaggregated.

${ }^{15} \mathrm{~A}$ comprehensive explanation can be found in Borghans, et al., Methodiek van het Informatiesysteem Onderwijs-Arbeidsmarkt 1995 (Methodology of the information system for education and the labour market 1995), ROA-W-1995/3, Maastricht, 1995. See also A. De Grip et al., Methodology of the ROA information system on occupational groups and type of education, ROA-W-1995/1E, 1995. 
Figure 2.1

General structure of the forecasting model for ROA's information system for education and the labour market

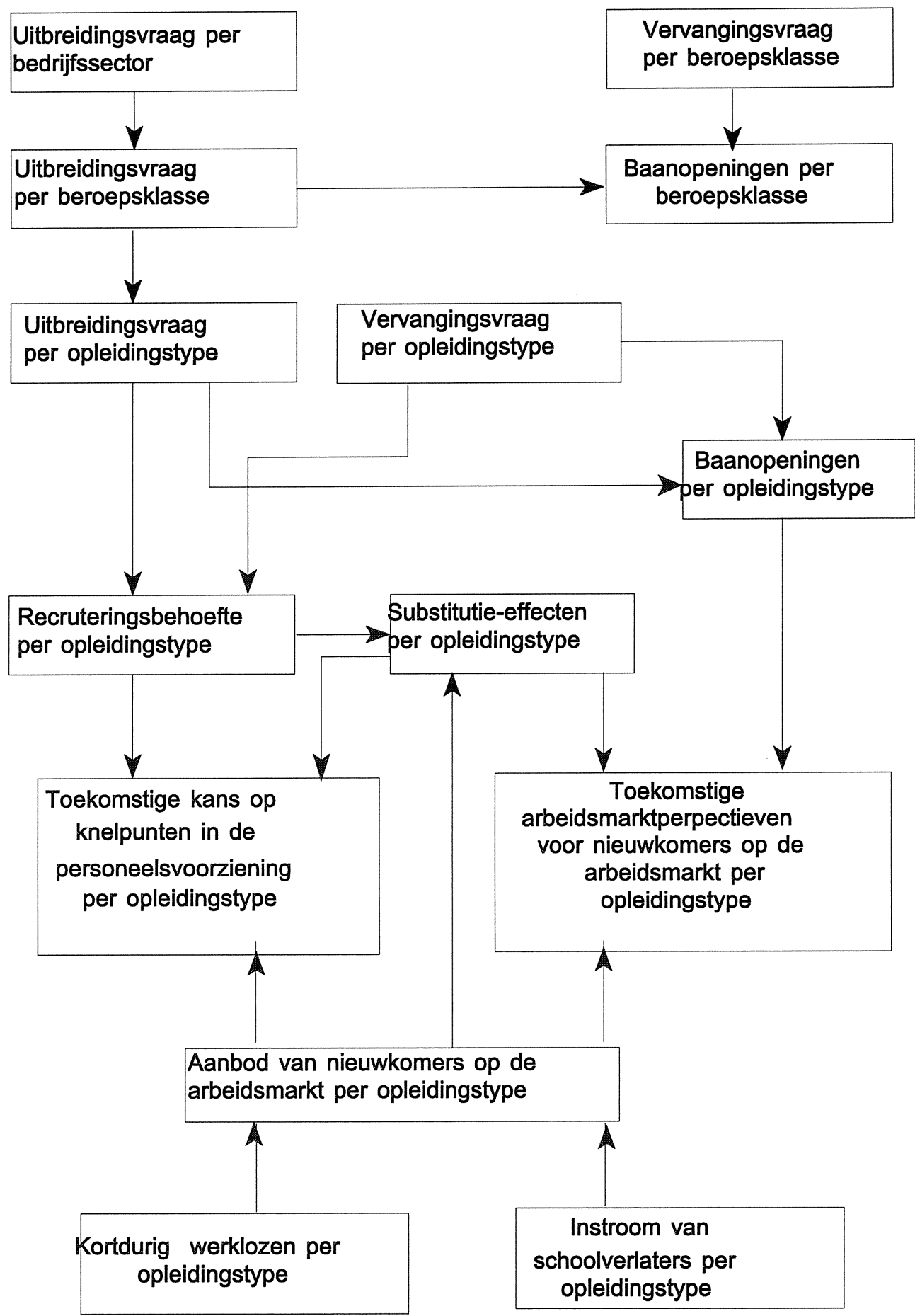

If employment levels are rising, the expansion demand and replacement demand together comprise the job openings for newcomers to the labour market. If employment levels are declining job openings can only arise due to replacement demand. 
In the labour market, the total demand for newcomers confronts the expected supply of newcomers, which consists of the future flow of school-leavers entering the market during the forecast period and the supply of short-term unemployed waiting to enter the market at the start of this period. It is assumed that the long-term unemployed, who have been looking for work for longer than a year, no longer constitute serious competition for school-leavers.

The forecasts of the flows of school-leavers entering the labour market correspond to the Referentieramingen 1995 (Reference forecasts) which are compiled by the Ministry of Education, Culture and Science for courses in the 'regular' (i.e., full-time initial) education system. ROA disaggregates these forecasts, and supplementary data is used to estimate the effects of the flows from non-regular education on the educational makeup of the flows entering the labour market. An allowance has also been made for the expected abolition of compulsory military training. In the forecast period this means that about 28,000 male school-leavers will flow directly onto the labour market instead of first completing their compulsory military training.

An indication of the future labour market prospects for newcomers to the labour market is derived, for each type of education, by confronting the expected flows of demand and supply with each other. This indicator shows what discrepancy may be expected between the demand and supply for each type of education. But excess supply does not imply that the group in question will as a matter of course become unemployed, and a supply shortfall does not automatically mean that there will be unfilled vacancies. In practice, it appears that school-leavers with a type of education for which the supply exceeds demand do suffer from a deterioration of their position, for example because they are more likely to have to accept work below their level, get less favourable contracts, are less well paid or more likely to work part-time involuntarily. ${ }^{16}$ In such a situation, employers would normally modify their demands and recruit people with a higher educational background than was originally contemplated. On the other hand, if there is a supply shortage the position of schoolleavers will improve, and they will then not have to accept a job at a lower level, for lower wages, etc.

Because of substitution processes, there will be less job openings for those with the types of education which suffer from 'crowding-out' by types of education with an excess supply. On the other hand, for those with educational backgrounds which are closely related to types of education which are in short supply, there will be extra job openings. These passive substitution effects are thus important determinants of the labour market prospects of types of education.

The confrontation between demand and supply also gives an indication of the future risk of labour recruitment problems for each type of education. The expansion and replacement demand jointly determine the recruitment requirement for each type of education. If employment for a particular type of education is declining, this recruitment requirement is calculated in a somewhat different manner than the number of job openings for newcomers to the labour market, because from the employers' point of view it is possible to achieve part of the retrenchment by limiting their

\footnotetext{
${ }^{16} \mathrm{M} . \mathrm{H}$. Wieling and L. Borghans, Discrepancies between Demand and Supply and Adjustment Processes on the Labour Market. ROA-RM-1995/5E, Maastricht, 1995.
} 
recruitment, so that fewer of the existing personnel have to be dismissed. Employers will be especially likely to use this option when they face a tight labour market for a particular type of education.

This chapter discusses the various flows of demand and supply which go to make up the labour market forecasts by education and occupation. These forecasts relate to the period 1995-2000, and are in each case compared with developments in the 1990-1994 period. Moreover qualitative characterizations have been assigned to both the expected and recent developments in each case. This characterization makes it possible to quickly interpret the relative magnitude of any particular movement, without attributing too much weight to slight differences between the precise figures. ${ }^{17}$ The chapter will begin with an outline of the expansion demand, for both occupational classes and types of education. This will include an explanation, at each point, of the underlying shifts in the economic sector and occupational structures. This will be followed by an examination of the expected replacement demand by occupational class and type of education. In discussing both the expansion demand and the replacement demand, attention will be focused in each case on those occupational classes and types of education for which, in absolute or relative terms, the highest or the lowest demand is expected. The following section will present the forecasts of the flows of school-leavers entering the labour market. Once again, the focus of attention will be on those types of education for which the flows are expected to exhibit the most marked changes. The chapter will close with an overview of the types of education which face the most pressure from crowding-out processes in the labour market. Chapter 3 will consider the expected employment prospects for the various types of education, and the indicators of the future risk of labour supply problems, in more detail. Chapter 4 will discuss the flexibility of the labour market and the substitution and crowdingout processes which are inter-related with this flexibility. A full picture of the demand and supply forecasts by occupation and education can be found in parts II and III of the Statistical Appendix.

\subsection{Expansion demand}

\section{Occupations}

Table 2.1 gives an overview of the occupational classes for which the expected expansion demand in the period 1995-2000 is highest, in absolute or relative terms. The relative magnitude of the expansion demand is expressed as the average annual rate of employment growth.

By far the highest expansion demand, in both absolute and relative terms, is expected for the occupational class of programmers and system analysts. With an average annual growth in employment of $8.4 \%$, the expansion demand over a 5 -year period is expected to add up to 67,000 new jobs. This means that the employment growth for this occupational class is expected to increase strongly in comparison to the average annual growth in the first half of the nineties of $2.3 \%$. The employment growth for this occupational class will be manifest particularly in the 'other commercial services' the 'financial services' and most of the manufacturing sectors.

\footnotetext{
${ }^{17}$ See M.H. Wieling, A. De Grip, E.J.T.A. Willems, Een systematische kwalitatieve typering van arbeidsmarktinformatie (A systematic qualitative characterization of labour market information), ROA-W-1990/8, Maastricht, for an explanation of the way in which these characterizations are determined.
} 
A large number of new jobs is also expected for a number of management, economic and commercial occupational classes and in the nursing and associated occupations. Over the whole period from 1995 to the year 2000, the expansion demand for the occupational class of managers and supervisors in manufacturing is expected to amount to more than 50,000 positions, while for senior finance and sales managers and accountants and economists, 18,000 and 16,000 jobs, respectively, are expected to be created. The growth in employment for the first of these occupational classes will take place mainly in the commercial services sectors, in construction, commerce and the chemical industry. The growth for the senior finance and sales managers is expected to be manifest in almost all sectors. In the early nineties employment for the management occupations actually fell slightly. The growth in employment for accountants and economists is expect to take place mainly in the other commercial services sector.

Sales assistants are expected to enjoy an expansion demand of more than 42,000 , with an additional increase of more than 15,000 expected in the number of shopkeepers, retail and wholesale staff. Furthermore, in contrast to developments in the preceding period, a substantial expansion demand is expected for the occupational class of commercial representatives, buyers and branch managers, who will benefit particularly from the expected growth in employment in commerce. The total expansion demand for the nursing and associated occupations is expected to amount to more than 30,000 jobs. Finally, although the growth in relative terms is not high, a substantial expansion demand is also expected for secondary and tertiary education teachers in the period $1995-2000$, with a total of more than 11,000 people.

Table 2.1

Occupational classes with the highest expansion demand 1995-2000 in absolute or relative terms (total numbers and average annual percentages)

absolute

Programmers and system analysts

Managers and supervisors in manufacturing

Sales assistants

Senior finance and sales managers

Nursing staff

Shopkeepers, retail and wholesale staff

Accountants and economists

Commercial reps., buyers and branch managers

Student nurses and home nursing personnel

Secondary and tertiary education teachers

Scientific researchers, technicians and statisticians

Geriatric help and kindergarten staff

relative

Programmers and system analysts

Accountants and economists

Agricultural and environmental engineers

Journalists and announcers

$\begin{array}{rllrl}66,700 & 8.4 & \text { very high } & 2.3 & \text { high } \\ 50,600 & 2.9 & \text { high } & -1.8 & \text { low } \\ 42,300 & 3.0 & \text { high } & 0.9 & \text { average } \\ 18,100 & 3.4 & \text { very high } & -0.2 & \text { average } \\ 16,600 & 2.8 & \text { high } & -2.0 & \text { low } \\ 15,700 & 1.8 & \text { high } & 4.6 & \text { very high } \\ 15,700 & 4.7 & \text { very high } & 4.4 & \text { very high } \\ 13,700 & 2.0 & \text { high } & -1.1 & \text { low } \\ 13,600 & 2.1 & \text { high } & 5.4 & \text { very high } \\ 11,100 & 1.3 & \text { average } & 2.4 & \text { high } \\ 10,000 & 3.3 & \text { very high } & -1.4 & \text { low } \\ 7,400 & 1.2 & \text { average } & 2.7 & \text { high }\end{array}$

$\begin{array}{rrrrl}66,700 & 8.4 & \text { very high } & 2.3 & \text { high } \\ 15,700 & 4.7 & \text { very high } & 4.4 & \text { very high } \\ 1,100 & 4.5 & \text { very high } & 3.1 & \text { high } \\ 7,200 & 4.0 & \text { very high } & 2.5 & \text { high }\end{array}$


Physiotherapists and occupational therapists Higher electrical engineers

Senior finance and sales managers

Scientific researchers, technicians and statisticians

Visual and performing artists

Librarians and archivists

Sales assistants

Managers and supervisors in manufacturing

$\begin{array}{rrlrl}6,600 & 3.8 & \text { very high } & -5.4 & \text { very low } \\ 2,700 & 3.5 & \text { very high } & -5.2 & \text { very low } \\ 18,100 & 3.4 & \text { very high } & -0.2 & \text { average } \\ 10,000 & 3.3 & \text { very high } & -1.4 & \text { low } \\ 6,000 & 3.1 & \text { high } & 1.3 & \text { average } \\ 2,700 & 3.0 & \text { high } & 8.3 & \text { very high } \\ 42,300 & 3.0 & \text { high } & 0.9 & \text { average } \\ 50,600 & 2.9 & \text { high } & -1.8 & \text { low }\end{array}$

Source: ROA

As in the first half of the nineties, the expansion demand in relative terms is expected to be highest in a number of occupations for which higher education is required. The growth in the number of new jobs, also in relative terms, will be highest for programmers and system analysts (8.4\% per year), followed by the accountants and economists, with an expansion demand averaging $4.7 \%$ per year. There is also a high relative expansion demand for three occupations which are typical of the hard sciences: agricultural and environmental engineers, higher electrical engineers and the occupational class of scientific researchers, technicians and statisticians. The new jobs for electrical engineers will come mainly in the economic sector of metal and electrical industries. In contrast, the growth in employment for the technical professions will take place largely in the sector of other commercial services and, to a somewhat lesser degree, also in non-commercial services. Employment for the higher electrical engineers and scientific researchers, technicians and statisticians fell in recent years at average rates of $5.2 \%$ and $1.4 \%$ per year, respectively, while employment for agricultural and environmental engineers also grew in the previous period, by an average of $3.1 \%$ per year.

The expansion demand for joumalists and announcers in the coming years, as in previous years, is expected to be high. A high expansion demand is also expected for the occupational class of physiotherapists and occupational therapists. Finally, there are also two occupational classes outside the hard sciences for which a high relative expansion demand is expected: the visual and performing artists and library and archive assistants. The expansion demand for librarians and archivists was also high in past years, while for visual artists the expansion demand in the period 1990-1994 was somewhat lower.

There are a number of occupational classes with a high or very high expansion demand for which it must be noted that the new jobs are often part-time jobs with flexible contracts. For the occupational classes of sales assistants, student nurses and home nursing personnel, geriatric help and kindergarten staff and physiotherapists and occupational therapists, both the percentage of workers with a flexible employment contract and the percentage with part-time work are high or very high. For nursing staff and librarians and archivists it is only the proportion of part-time employment that is high.

Although employment growth is expected for the majority of the 93 occupational classes which we have differentiated, employment is expected to decline to some extent for some 38 occupational classes. Of these, 26 occupational classes also suffered falling employment in the first half of the nineties. 
Table 2.2 gives an overview of the occupational classes for which the employment is expected to decline most sharply, in absolute or relative terms. The table shows that the largest decline in the number of jobs is expected for the purchasing and sales clerks, who would generally have intermediate-level education. This drop in employment is a result of the falling number of jobs for intermediate-trained administrative personnel in the financial services sector. This is also the main cause of the decrease in employment for the occupational class of book-keepers and bank employees, although in the latter case the decline is exacerbated by falling employment in the government sector (i.e., the civil service, police, defense and education). Both occupational classes were actually growing in previous years. 
Table 2.2

Occupational classes with the lowest expansion demand, in absolute or relative terms, 1995-2000 (total numbers and average annual percentages)

\begin{tabular}{llll} 
Occupational class & forecast $1995-2000$ & \multicolumn{2}{c}{ 1990-1994 } \\
number $\%$ & character. & $\%$ & character. \\
\hline
\end{tabular}

absolute

Purchasing and sales clerks

Porters, cleaners and domestics

Farmers

Agricultural workers

Military professionals

Carpenters and woodworkers

Book-keepers and bank employees

Civil servants (public administration)

Road construction workers and pipelayers

Hairdressers and beauticians

Primary and special education teachers

Plumbers

relative

Military professionals

Civil servants (public administration)

Agricultural workers

Datatypists and computer operators

Textile production workers

Farmers

Upholsterers, shoemakers and leatherworkers

Clothing production workers and sailmakers

Porters, cleaners and domestics

Hairdressers and beauticians

Intermediate mechanical engineers

Glaziers and concreting hands

$\begin{array}{rrlrl}-23,000 & -1.3 & \text { low } & 2.9 & \text { high } \\ -17,000 & -2.3 & \text { low } & -0.2 & \text { average } \\ -15,300 & -2.5 & \text { very low } & -1.6 & \text { low } \\ -14,400 & -2.8 & \text { very low } & -6.9 & \text { very low } \\ -8,800 & -6.4 & \text { very low } & -3.9 & \text { very low } \\ -6,700 & -1.1 & \text { low } & 0.7 & \text { average } \\ -6,700 & -0.4 & \text { average } & 2.1 & \text { high } \\ -5,100 & -4.0 & \text { very low } & 0.5 & \text { average } \\ -4,000 & -1.4 & \text { low } & -10.7 & \text { very low } \\ -3,800 & -2.3 & \text { low } & 2.0 & \text { high } \\ -3,200 & -0.7 & \text { low } & -0.5 & \text { average } \\ -3,100 & -1.6 & \text { low } & -3.9 & \text { very low }\end{array}$

$\begin{array}{rrlrl}-8,800 & -6.4 & \text { very low } & -3.9 & \text { very low } \\ -5,100 & -4.0 & \text { very low } & 0.5 & \text { average } \\ -14,400 & -2.8 & \text { very low } & -6.9 & \text { very low } \\ -1,500 & -2.8 & \text { very low } & -4.1 & \text { very low } \\ -1,100 & -2.6 & \text { very low } & -4.8 & \text { very low } \\ -15,300 & -2.5 & \text { very low } & -1.6 & \text { low } \\ -2,100 & -2.4 & \text { very low } & -0.9 & \text { low } \\ -1,900 & -2.4 & \text { very low } & -5.7 & \text { very low } \\ -17,000 & -2.3 & \text { low } & -0.2 & \text { average } \\ -3,800 & -2.3 & \text { low } & 2.0 & \text { high } \\ -1,200 & -1.9 & \text { low } & -0.4 & \text { average } \\ -2,200 & -1.8 & \text { low } & 2.1 & \text { high }\end{array}$

Source: ROA

One trend which has been observable for more than a decade now is the decline in employment opportunities in lower-level functions. But the rapidity of this decline has increased and the accent has gradually shifted from industrial production workers to occupations such as porters, cleaners and domestics, for whom total employment is expected to decrease by 17,000 jobs over the coming years, in contrast to the trend in the previous period. This decline in employment is occuring because the employment share of this occupation in the non-commercial services sector is declining. The decline in employment for the lower agricultural functions, on the other hand, continues the long-term employment trend in these occupations. The agricultural workers are expected to face employment cuts of almost 15,000 jobs over the coming five years. However the expected decline in employment for the farmers is even more serious. Many agricultural workers are switching occupations at a time when developments in the labour market are relatively favourable. ${ }^{18}$

${ }^{18}$ See also Central Planning Bureau, Athena. Een bedrijfstakkenmodel voor de Nederlandse economie (Athena, a sector model of the Dutch economy), Monograph No. 30, Den Haag, 1990. 
The upturn in the business cycle should make it possible for many agricultural workers to leave the agricultural sector. Declining employment is also expected for a number of building and construction occupations. The largest number of jobs will be lost among carpenters and woodworkers, who had enjoyed a slight growth over the past years, and among the road construction workers and pipelayers, who have been facing falling employment levels for some time.

For the first time, the stagnation of employment in the government sector will be reflected in a fall in the number of jobs for civil servants (public administration). An even greater decline in employment is expected to be seen among military professionals, as a result of cutbacks in the armed forces. The lower part of the table shows that the military professionals and civil servants (public administration) face the most serious declines in employment, in relative terms, with average annual falls of more than $6 \%$ and $4 \%$, respectively. The relative reduction in employment is also serious for agricultural workers and farmers.

There are also a number of lower-level occupations for which the decline in employment is not very large in absolute terms, but is certainly considerable in relative terms. These are occupational classes which have already suffered large relative declines in employment levels over recent years: the datatypists and computer operators, textile production workers, upholsterers, shoemakers and leatherworkers and clothing production workers and sailmakers. The disappearance of work for datatypists and computer operators results from the ongoing computerisation process, which in this case is causing a clear upgrading of the level of the work. The decline in employment in the other three occupational classes results from the stagnation of employment in the manufacturing sectors in which the workers in these occupational classes find employment.

\section{Types of education}

The divergent movements in employment levels across economic sectors and the shifts in the occupational structure within economic sectors largely determine the demand for workers with a particular educational background. But even within occupations there may be shifts in the educational qualifications which employers demand, and these can have a large influence on the expansion demand for a particular type of education. Chapter 4 will include a closer examination of shifts in the labour market position of types of education as a result of changes in employment levels in economic sectors, shifts between occupational classes and changes in the demand for particular types of education. 
Table 2.3

Types of education with the highest expansion demand, in absolute or relative terms, 1995-2000 (total numbers and average annual percentages)

Type of education

forecast $1995-2000$

number $\%$ character.

1990-1994

$\% \quad$ character.

absolute

IVE, Retail

Higher General Secondary Education

HVE, Teacher training

IVE, Nursing and paramedical services

UE, Economics, econometrics and business admin.

UE, Social sciences

HVE, Nursing and paramedical services

HVE, Social and cultural

IVE, Police, fire and defense

HVE, Electronic and information technology

HVE, Commercial information science

UE, Mathematics and natural sciences

relative

HVE, Commercial information science

UE, Information science

UE, Economics, econometrics and business admin.

UE, Management science

UE, Electrical engineering and information tech.

PVE, Security

HVE, Electronic and information technology

HVE, Accounting

UE, Public administration

UE, Mathematics and natural sciences

UE, Mechanical engineering

HVE, Business administration technology

HVE, Technical laboratory

\begin{tabular}{|c|c|c|c|}
\hline $22,1001.3$ & average & 2.1 & average \\
\hline $20,7001.3$ & average & 2.2 & average \\
\hline $18,5001.4$ & average & 2.6 & average \\
\hline $16,4001.7$ & average & 1.5 & average \\
\hline $14,9006.0$ & very high & 4.5 & very high \\
\hline $14,8003.4$ & high & 4.0 & high \\
\hline $14,4003.2$ & high & 2.6 & average \\
\hline $14,1002.3$ & average & 3.1 & high \\
\hline $13,5003.1$ & high & 4.5 & very high \\
\hline $11,2004.8$ & very high & 3.1 & high \\
\hline $10,4006.3$ & very high & 3.4 & high \\
\hline $9,4004.1$ & high & 2.1 & average \\
\hline
\end{tabular}

$10,4006.3$

$1,5006.1$

very high

very high

$14,9006.0$ very high

$3,2005.7$ very high

$4,2005.5$ very high

3,200 5.5 very high

$11,2004.8$

very high

$7,0004.5$ very high

$2,4004.4$ very high

$9,4004.1$ high

$1,9004.0$ high

$2,8004.0$ high

$6,0004.0$ high

$\begin{array}{ll}3.4 & \text { high } \\ 4.8 & \text { very high } \\ 4.5 & \text { very high } \\ 3.8 & \text { high } \\ 2.1 & \text { average } \\ 5.9 & \text { very high } \\ 3.1 & \text { high } \\ 3.2 & \text { high } \\ 4.4 & \text { very high } \\ 2.1 & \text { average } \\ 2.0 & \text { average } \\ 1.7 & \text { average } \\ 1.4 & \text { average }\end{array}$

Source: ROA

Table 2.3 gives an overview of the types of education for which the largest expansion demand is expected in the period 1995-2000, in absolute or relative terms. In absolute terms, the expansion demand is highest for Intermediate Vocational Education, Retail and Higher General Secondary Education. Almost all of the types of education in the list of those for which the relative expansion demand is expected to be highest are at the Higher Vocational Education or University level. The only exception is non-regular Preparatory Vocational Education in Security, which can also look forward to very high expansion demand. The relative expansion demand is highest for Higher Vocational Education, Commercial information science, and for University Education in Information science and Economics, econometrics and business administration, with average annual growth rates of $6.3 \%, 6.1 \%$ and $6.0 \%$ respectively. The expansion demand for these types of education was already high in the first half of the nineties. The high expansion demand for these types of education is due mainly to the high expansion demand for programmers and system analysts, accountants and economists and senior finance and sales managers. 
A high growth in demand is also expected for studies in management and public administration at university level and for Higher Vocational Education, Accounting. Once again these movements continue the growth in previous years. The high expansion demand for University Education, Management science and University Education, Public administration is due mainly to the high demand for programmers and system analysts, accountants and economists and senior finance and sales managers. Moreover, University Education, Public administration benefits from the upgrading of the qualifications demanded in the occupations in which workers with such an educational background are employed. This will be discussed further in chapter 4 .

Three higher technical types of education are among those with the highest expansion demand. These are the Higher Vocational Education and University Education in Electrical engineering and information technology and University Education, Mathematics and natural sciences. Once again, the growth for these three types of education is a continuation of the trend over recent years. The expansion demand for Electrical engineering and information technology at Higher Vocational Education and University Education levels is due to the strong demand for higher electrical engineers, programmers and system analysts and managers and supervisors in manufacturing. Likewise, University Education, Mathematics and natural sciences benefits from the ever-growing demand for system analysts, but also from the expected growth in employment for secondary and tertiary education teachers and scientific researchers, technicians and statisticians.

Just as there are occupations which face falling employment levels, 17 of the 78 types of education which we distinguish in this study face falling employment. Table 2.4 shows that by far the most serious fall in employment, in terms of numbers of workers, is for the workers without any educational qualifications. These are people who have only had primary education or who dropped out of their further education without any diploma. Over the coming five years this 'hard core of school drop-outs' are expected to lose a total of almost 67,000 positions. The falling demand for workers without any educational qualifications is largely attributable to employers becoming less willing to hire them, but employment in the occupations in which many people without educational qualifications find work is also falling (see also section 4.6). This is a development which has already been underway for some time, but it is only in recent years that the decline in employment in these occupational classes has exceeded the decline in the supply of labour with only lower-level qualifications, so that even if there were no changes in the qualifications which employers demand there would still be a surplus.

Most of the other types of education for which employment will fall most strongly in absolute terms are also below the level of a 'basic qualification', i.e., they are below the level of Intermediate Vocational Education or an apprenticeship qualification. These are mainly people with Lower General Secondary Education or a technical education at the Preparatory Vocational Education level. Those with Lower General Secondary Education, like workers without any qualifications, suffer mainly from an increasing tendency among employers to demand a vocational education diploma which is relevant to the occupation concerned. People with Lower General Secondary Education are increasingly being crowded out of the intermediate administrative occupations, such as secretaries and typists, telephonists, receptionists and pollsters, and the intermediate level commercial occupations: shopkeepers, retail and wholesale staff and commercial representatives, 
buyers and branch managers. Those with a technical education at the Preparatory Vocational Education level suffer mainly from the upgrading of the qualifications demanded in many technical trades for which people with Intermediate Vocational Education are increasingly being recruited. ${ }^{19}$

${ }^{19}$ See also L. Borghans, A. de Grip and W. Smits, Beroepsmobiliteit van technisch opgeleiden (Occupational mobility among people with a technical education), OSA working document D1, Den Haag, 1995. 
Table 2.4

Types of education with the lowest expansion demand, in absolute or relative terms, 1995-2000 (total numbers and average annual percentages)

Type of education forecast 1995-2000 1990-1994

number $\%$ character. $\%$ character.

absolute

Primary Education

Lower General Secondary Education

PVE, Construction trades

PVE, Mechanical trades

PVE, Agriculture

PVE, Community care, hotel and catering

PVE, Administration

PVE, Electrical trades

PVE, Automobile trades

IVE, Agriculture and the natural environment

PVE, Textile and leather trades

PVE, Transport and harbour

relative

Primary Education

PVE, Agriculture

PVE, Administration

PVE, Construction trades

PVE, Mechanical trades

PVE, Utilities installation

PVE, Automobile trades

PVE, Electrical trades

Lower General Secondary Education

PVE, Textile and leather trades

PVE, Printing trades

PVE, Food trades

$\begin{array}{rrlrl}-66,300 & -2.8 & \text { very low } & -5.2 & \text { very low } \\ -18,400 & -0.9 & \text { low } & 0.2 & \text { low } \\ -8,300 & -1.2 & \text { low } & -0.7 & \text { low } \\ -7,800 & -1.2 & \text { low } & -1.2 & \text { low } \\ -7,100 & -1.9 & \text { very low } & -2.7 & \text { very low } \\ -6,400 & -0.6 & \text { low } & 0.2 & \text { low } \\ -3,800 & -1.3 & \text { low } & 0.7 & \text { average } \\ -2,900 & -1.0 & \text { low } & -0.8 & \text { low } \\ -2,700 & -1.1 & \text { low } & -0.4 & \text { low } \\ -2,100 & -0.3 & \text { low } & -0.5 & \text { low } \\ -1,100 & -0.9 & \text { low } & 0.7 & \text { average } \\ -900 & -0.5 & \text { low } & 1.8 & \text { average }\end{array}$

$\begin{array}{rrlll}-66,300 & -2.8 & \text { very low } & -2.2 & \text { very low } \\ -7,100 & -1.9 & \text { very low } & -2.7 & \text { very low } \\ -3,800 & -1.3 & \text { low } & 0.7 & \text { average } \\ -8,300 & -1.2 & \text { low } & -0.7 & \text { low } \\ -7,800 & -1.2 & \text { low } & -1.2 & \text { low } \\ -500 & -1.1 & \text { low } & -1.9 & \text { very low } \\ -2,700 & -1.1 & \text { low } & -0.4 & \text { low } \\ -2,900 & -1.0 & \text { low } & -0.8 & \text { low } \\ -18,400 & -0.9 & \text { low } & 0.2 & \text { low } \\ -1,100 & -0.9 & \text { low } & 0.7 & \text { average } \\ -200 & -0.7 & \text { low } & -2.8 & \text { very low } \\ -700 & -0.7 & \text { low } & -0.3 & \text { low }\end{array}$

Source: ROA

In terms of numbers of workers, the greatest decrease in demand at the level of Intermediate Vocational Education and apprenticeships is expected, as in past years, for those with agricultural education. This decline in demand is entirely due to the continuing decline in employment in the agricultural sector.

In relative terms the decline in employment is once again most marked for workers without educational qualifications. The average demand for those without educational qualifications is expected to decline by more than $2.8 \%$ per year. There is also a large relative decline in demand for Preparatory Vocational Education, agriculture. The other types of education in the list of those with the most strongly declining demand are all at a low educational level. In addition to various technical fields of study at the level of Preparatory Vocational Education, this includes Preparatory Vocational Education, Administration and Lower General Secondary Education.

\subsection{Replacement demand}




\section{Occupations}

As we have already seen in Table 1.1, replacement demand is generally responsible for the majority of job openings. But not every person among the $3.3 \%$ of workers who leave the labour market each year is replaced by a new employee in the same occupational class. In some cases there are employment cuts. Moreover, replacement demand for an occupation is affected not only by the need to replace workers who are retiring, suffer work disability or temporarily withdraw from the labour market, but also by the demand arising from workers' switching to other occupational classes.

The average replacement demand for all occupational classes for the period 1995-2000 is expected to be $3.8 \%$ per year. This is an increase compared to the first half of the nineties, when the average annual replacement demand for all occupational classes was just $3.1 \%$. The greatest need for replacement workers, in absolute terms, will be for managers and supervisors in manufacturing. Over the coming five years more than 75,000 jobs for this occupational class are expected to fall vacant because of the departure of the present personnel. This high staff turnover is mainly because these positions are typically reached only at the end of a worker's career, so that a large proportion of the workers are more than 50 years old.

Large numbers of jobs for book-keepers and bank employees and purchasing and sales clerks are also expected to fall vacant. The total figures are somewhat over 63,000 and almost 50,000, respectively. But in these large occupational classes the replacement demand is not very great as a proportion of the labour force in the class. Many jobs for sales assistants are also expected to fall vacant, but what is most striking about this occupational class is the high loss of personnel in the very young age group, of 25-30 years. The high number of jobs for drivers and conductors which will fall vacant is the result of a relatively high outflow of workers in the comparatively young age group of $35-40$ years.

The highest relative replacement demand is expected for civil servants (public administration). This is mainly the result of the high average age of these professions. Almost $30 \%$ of the workers are 50 years old or older, which is about twice the average figure. In contrast, the high replacement demand for student nurses and home nursing personnel has an entirely different cause. The student nurses leave this occupational class more or less automatically when they have completed the training. Moreover, many women work in this occupational class, and they often withdraw from the labour market at a young age in connection with raising children. This is also a factor for other typical female occupations such as nursing staff and secretaries and typists. For the first of these classes a considerable number of people are leaving the occupation as young as to 30 years old. For secretaries and typists there is an especially large loss of personnel, in relative terms, at about the age of 35 , and the number of people taking early retirement is also high in comparison with other occupations. 
Table 2.5

Occupational classes with the highest replacement demand, in absolute or relative terms, 1995-2000 (total numbers and average annual percentages)

absolute

Managers and supervisors in manufacturing

Book-keepers and bank employees

Purchasing and sales clerks

Sales assistants

Drivers and conductors

Student nurses and home nursing personne

Secondary and tertiary education teachers

Secretaries and typists

Shopkeepers, retail and wholesale staff

Porters, cleaners and domestics

Commercial reps., buyers and branch managers

Programmers and system analysts

relative

Intermediate electrical engineers

Civil servants (public administration)

Student nurses and home nursing personnel

Machinery mechanics and instrument makers

Pastoral vocations

Painters

Hotel and catering owners and supervisors

Secretaries and typists

Senior finance and sales managers

Nursing staff

Bricklayers and plasterers

Community workers and probation officers

Doctor's, dentist's and vetinary assistants

$\begin{array}{lllll}76,100 & 4.2 & \text { average } & 3.3 & \text { low } \\ 63,200 & 3.3 & \text { average } & 2.4 & \text { very low } \\ 49,900 & 2.6 & \text { low } & 2.0 & \text { very low } \\ 48,000 & 3.4 & \text { average } & 2.8 & \text { low } \\ 45,900 & 4.5 & \text { high } & 3.3 & \text { average } \\ 38,900 & 5.6 & \text { very high } & 6.3 & \text { very high } \\ 37,600 & 4.3 & \text { average } & 2.6 & \text { low } \\ 36,600 & 4.9 & \text { high } & 3.5 & \text { average } \\ 32,300 & 3.5 & \text { average } & 3.2 & \text { low } \\ 31,500 & 3.8 & \text { average } & 2.6 & \text { low } \\ 31,100 & 4.4 & \text { high } & 3.8 & \text { average } \\ 30,800 & 4.2 & \text { average } & 2.5 & \text { low }\end{array}$

$\begin{array}{lllll}1,800 & 5.9 & \text { very high } 4.3 \quad \text { average }\end{array}$

$9,000 \quad 5.8 \quad$ very high 4.2 average

$38,900 \quad 5.6$ very high 6.3 very high

$19,300 \quad 5.4$ very high 4.4 average

$2,300 \quad 5.3 \quad$ very high $5.3 \quad$ very high

$9,500 \quad 5.2$ very high 4.5 high

$18,200 \quad 4.9$ high 4.4 average

$36,600 \quad 4.9$ high $\quad 3.5 \quad$ average

$26,300 \quad 4.8$ high 4.3 average

$29,600 \quad 4.8$ high 4.1 average

$\begin{array}{lllll}12,000 & 4.8 & \text { high } & 4.1 & \text { average }\end{array}$

$\begin{array}{lllll}17,900 & 4.7 & \text { high } & 3.0 & \text { low }\end{array}$

$\begin{array}{lllll}6,000 & 4.7 & \text { high } & 3.1 & \text { low }\end{array}$

Source: ROA 
Table 2.6

Occupational classes with in absolute or relative terms the lowest replacement demand 1995-2000 (total number of and average annual percentage)

absolute

Fishermen and gamekeepers

Electricity and gas supply workers

Agricultural and environmental engineers

Sailors, deckhands and engine-room workers

Vetinary surgeons

Dentists and dental specialists

Datatypists and computer operators

Translators and other literary professions

Ship's officers and marine inspectors

Smelter workers and drilling hands

Intermediate electrical engineers

Sports instructors in secondary education

Higher mechanical engineers

relative

Technical and medical representatives

Fishermen and gamekeepers

Datatypists and computer operators

Sailors, deckhands and engine-room workers

Agricultural workers

Road construction workers and pipelayers

Military professionals

Electricity and gas supply workers

Agricultural and environmental engineers

Architects and construction engineers

Purchasing and sales clerks

Ship's officers and marine inspectors

Personnel officers and vocational advisors

Hairdressers and beauticians

$\begin{array}{rllll}300 & 2.0 & \text { very low } & 3.7 & \text { average } \\ 400 & 2.4 & \text { very low } & 2.0 & \text { very low } \\ 600 & 2.4 & \text { low } & 1.5 & \text { very low } \\ 600 & 2.1 & \text { very low } & 1.5 & \text { very low } \\ 600 & 3.3 & \text { average } & 0.4 & \text { very low } \\ 1,200 & 4.3 & \text { average } & 1.8 & \text { very low } \\ 1,200 & 2.0 & \text { very low } & 0.8 & \text { very low } \\ 1,400 & 4.0 & \text { average } & 2.1 & \text { very low } \\ 1,500 & 2.7 & \text { low } & 3.8 & \text { average } \\ 1,800 & 3.0 & \text { low } & 1.4 & \text { very low } \\ 1,800 & 5.9 & \text { very high } & 4.3 & \text { average } \\ 1,900 & 2.8 & \text { low } & 1.7 & \text { very low } \\ 1,900 & 3.5 & \text { average } & 2.7 & \text { low }\end{array}$

$\begin{array}{rllll}2,300 & 1.9 & \text { very low } & 0.5 & \text { very low } \\ 300 & 2.0 & \text { very low } & 3.7 & \text { average } \\ 1,200 & 2.0 & \text { very low } & 0.8 & \text { very low } \\ 600 & 2.1 & \text { very low } & 1.5 & \text { very low } \\ 12,300 & 2.2 & \text { very low } & 1.8 & \text { very low } \\ 7,100 & 2.3 & \text { very low } & 0.9 & \text { very low } \\ 3,800 & 2.3 & \text { very low } & 1.8 & \text { very low } \\ 400 & 2.4 & \text { very low } & 2.0 & \text { very low } \\ 600 & 2.4 & \text { low } & 1.5 & \text { very low } \\ 4,300 & 2.5 & \text { low } & 2.0 & \text { very low } \\ 49,900 & 2.6 & \text { low } & 2.0 & \text { very low } \\ 1,500 & 2.7 & \text { low } & 3.8 & \text { average } \\ 4,900 & 2.7 & \text { low } & 1.6 & \text { very low } \\ 4,900 & 2.7 & \text { low } & 1.9 & \text { very low }\end{array}$

Source: ROA

For most of the occupational classes in the table, the relative replacement demand was also high in the first half of the nineties. The clearest example of this pattern is the pastoral vocations, which had long had a strong need for replacement staff. Almost half of the workers are now 50 years old or older, and a considerable proportion of these are older than 65 and still practising their vocation. This is partly due to the problem of finding successors for pastors and clergy who would like to retire. In addition to the pastoral vocations, high replacement demand is expected for a number of building and construction occupations. This is mainly due to the relatively high outflow of workers of 45 years old and above. Occupations such as bricklayers and plasterers are often too physically taxing at this age, so that there is a flow of workers departing to other, less taxing, occupations or withdrawing from the labour force with disabilities. The result is that only a relatively low proportion of the workers in these occupations are 50 or more years old. The same pattern, although to a less marked extent, can be observed among the painters. For the construction occupation of plumbers, 
in contrast, the flows of workers leaving the occupational class before retirement age are very much lower. Apparently the physical exertions required in this construction occupation are less extreme, so that it is possible for older workers to continue to practice the occupation.

As Table 2.6 shows, the occupational classes of agricultural and environmental engineers and sailors, deckhands and engine-room workers, which have relatively few workers, are expected to offer low replacement demand in both absolute and relative terms. The replacement demand is also expected to be low for datatypists and computer operators and ship's officers and marine inspectors. In the case of datatypists and computer operators this is mainly because the positions which will fall vacant with the departure of those who are at present working in this occupation will not be filled, and there is thus scarcely any replacement demand within this occupational group. For ship's officers and marine inspectors, in contrast, the cause of the low replacement demand is the relatively low flows of people leaving the occupational class, which indicates that workers remain active in this occupation for a long time. Although a high proportion of the workers in this occupation are 50 or older, and a fairly high proportion retire early, the net effect is still a relatively low need for replacement personnel.

The reasons of the low levels of relative replacement demand for the other occupational classes in the table also differ widely. Some occupations face falling demand in the coming years, which will reduce the need to replace the current workers. This is especially so for agricultural workers, road construction workers and pipelayers and military professionals. Where employment has recently been growing strongly, the relative replacement demand will also generally be low. For example, personnel officers and vocational advisors was one of the most rapidly growing occupational classes on the labour market of the first half of the nineties. But the down side of this is that a relatively high proportion of the workers are still at an early stage of their careers, which means that only a small proportion will leave the occupation in the coming years. The same phenomenon was also noted earlier in relation to the programmers and system analysts, but it has now become apparent that the picture for the latter occupational class will change considerably in the coming years. A high proportion of the programmers and system analysts who entered these occupations when they were booming in the eighties are now reaching an age, at about 35 years, at which new career opportunities open up. This will lead to occupational mobility to other occupations, either within the enterprises in which they are now working or elsewhere. One could call this the 'up or out' phase, in which programmers and system analysts either find employment in other, more management-oriented, occupations in the field of computers and automation, or enter entirely different fields.

In contrast, both architects and construction engineers and hairdressers and beauticians are typically end-phase occupations, from which the mobility to other occupations is very low. For architects and construction engineers the number of workers who are 50 years old or older is actually high, but the effect of this in increasing the replacement demand is more than counterbalanced by the fact that people stay in this occupational class for a relatively long time. The hairdressers and beauticians have a very peculiar pattern of flows out of the profession: a considerable proportion of the young women in this occupational class withdraw before they are 30 , but for those who stay - most of whom are men - the flows leaving the occupation are no higher than average. 


\section{Types of education}

The increasing aging of the population and of the labour force will also cause the replacement demand per type of education to increase sharply in the second half of the nineties. Almost all of the $3.3 \%$ of workers who leave the labour market each year need to be replaced. Those for whom a successor with the same educational background is not sought, because the demand for that type of education has fallen, amount to just $0.3 \%$ of the outflow. In the first half of this decade the replacement demand averaged only a little over $2 \%$ per year, but for the coming five years this is expected to increase to an average of almost $3 \%$ per year. This means that a total of some 300,000 additional positions will fall vacant and have to be filled.

High replacement demand, in absolute terms, is expected for a number of large types of education, especially at Intermediate Vocational Education and apprenticeship level (see Table 2.7). These are largely courses in the fields of commerce, nursing and paramedical services, personal services and construction. In absolute terms the highest replacement demand is expected for workers without any educational qualifications, but it must be remembered that the flows of workers with no more than primary education leaving the labour force are much higher than this. However a considerable proportion of the jobs which fall vacant will not be filled by people without any educational qualifications (see also Table 2.3), so that the replacement demand for this type of education will be significantly lower than the outflow.

The general increase in the need for replacements can be clearly seen in the list of types of training with a high relative replacement demand. The replacement demand is expected to be highest for University Education, Theology. This picture, which is consistent with the expectations for the pastoral vocations, has already been evident for some time. There is also expected to be a very high need for replacement workers educated in textile and leather trades at the Preparatory Vocational Education level. This is connected mainly to the large number of older people, especially women, with such an educational background who are now working but will be leaving the labour market soon.

One striking shift is expected for University Education, Veterinary and medical sciences and dentistry, for which the replacement demand will increase considerably in the coming years because many of the male doctors will be reaching retirement age. However there is a striking difference in the expected outflows of men and women with this educational background. The relatively high average age of the men will mean a very large outflow, whereas for female doctors the flows leaving the labour market are expected to be small, because they have only come onto the labour market in relatively large numbers in recent years.

Table 2.7

Types of education with the highest replacement demand, in absolute or relative terms, 1995-2000 (total numbers and average annual percentages) 
absolute

Primary Education

$68,9002.6$

average $\quad 1.4$

very low

IVE, Retail

$64,0003.7$

$55,8002.6$

Lower General Secondary Education

very high 2.9

average

$50,9003.7$

average $\quad 1.6$

very high 1.6

$39,1003.6$

PVE, Community care, hotel and catering

high

low

$34,3003.5$

IVE, Nursing and paramedical services

$33,0002.0$

Higher General Secondary Education

$31,5002.7$

IVE, Community care

$26,8003.0$

IVE, Construction technology

$21,1002.9$

PVE, Mechanical trades

$19,1002.6$

high

average

average 2.6

very low

low

low

very low

low

average

average 1.7 very low

average 2.4 low

relative

UE, Theology

$1,7005.6$

very high

5.2

very high

$6,9005.2$

very high 5.6

very high 2.2

UE, Veterinary and medical sciences and dentistry

$50,9003.7$

very high 1.6

very high

low

$64,0003.7$

IVE, Retail

$7,3003.7$

very high 2.9

very low

average

$3,1003.7$

very high 2.3

very high 3.8

low

$5,0003.6$

very high 3.0

$5,5003.6$ very high 2.7

very high

average

HVE, Legal and fiscal

$8,2003.6$

high

average

UE, Mathematics and natural sciences

$8,9003.6$

very high

IVE, Transport and harbour

$39,1003.6$

high

high

low

Source: ROA

The replacement demand for those with teacher training at Higher Vocational Education level will also increase considerably in the coming years, in comparison with the first half of the nineties. Workers with this educational background remain in the labour market for a relatively long time, but this has also lead to a situation in which the average age has now become quite high, which will lead to increased flows out of the labour market in the coming years. Not only is the average age increasing, these workers are also leaving while still relatively young as a result of the special arrangements for older workers, and other measures. Furthermore, the effects of the relatively high percentages of workers who are 50 or more years old, among those with the types of education University Education, Mathematics and natural sciences and Higher Vocational Education, Accounting, are clearly visible. For both of these types of education, the need for replacement workers is expected to be higher than in past years. For Higher Vocational Education in the administrative, legal and fiscal fields and for those educated in Precision engineering at the Intermediate Vocational Education or apprenticeship level, the replacement demand in coming years is expected to be comparable to that in the previous period. The replacement demand for both types of education was also relatively high in the first half of this decade.

\section{Table 2.8}

Types of education with the lowest replacement demand, in absolute or relative terms, 1995-2000 (total numbers and average annual percentages) 
absolute

HVE, Tourism and recreation

UE, Information science

IVE, Tourism and recreation

UE, Pharmacy

PVE, Printing trades

PVE, Security

PVE, Utilities installation

HVE, Business administration technology

UE, Agriculture and environmental science

HVE, Interpreter and translator

UE, Public administration

relative

PVE, Commerce

IVE, Tourism and recreation

HVE, Tourism and recreation

PVE, Food trades

PVE, Administration

HVE, Commerce

HVE, Business administration technology

IVE, Commerce

HVE, Commercial information science

UE, Agriculture and environmental science

Higher General Secondary Education

HVE, Medical laboratory

HVE, Business administration

$\begin{array}{rllll}400 & 1.1 & \text { very low } & 0.5 & \text { very low } \\ 500 & 2.2 & \text { low } & 0.9 & \text { very low } \\ 700 & 0.9 & \text { very low } & 0.2 & \text { very low } \\ 700 & 2.7 & \text { average } & 0.8 & \text { very low } \\ 800 & 2.1 & \text { low } & 0.6 & \text { very low } \\ 1,100 & 2.1 & \text { low } & 1.4 & \text { very low } \\ 1,200 & 2.4 & \text { average } & 1.3 & \text { very low } \\ 1,200 & 1.8 & \text { very low } & 1.5 & \text { very low } \\ 1,200 & 1.9 & \text { low } & 0.8 & \text { very low } \\ 1,300 & 2.9 & \text { average } & 1.8 & \text { low } \\ 1,300 & 2.4 & \text { average } & 2.5 & \text { average }\end{array}$

$\begin{array}{rllll}1,500 & 0.9 & \text { very low } & 0.5 & \text { very low } \\ 700 & 0.9 & \text { very low } & 0.2 & \text { very low } \\ 400 & 1.1 & \text { very low } & 0.5 & \text { very low } \\ 1,700 & 1.7 & \text { very low } & 0.5 & \text { very low } \\ 5,800 & 1.8 & \text { very low } & 1.3 & \text { very low } \\ 1,900 & 1.8 & \text { very low } & 1.1 & \text { very low } \\ 1,200 & 1.8 & \text { very low } & 1.5 & \text { very low } \\ 3,500 & 1.9 & \text { low } & 1.5 & \text { very low } \\ 2,900 & 1.9 & \text { low } & 1.4 & \text { very low } \\ 1,200 & 1.9 & \text { low } & 0.8 & \text { very low } \\ 33,000 & 2.0 & \text { low } & 1.7 & \text { very low } \\ 2,300 & 2.0 & \text { low } & 1.4 & \text { very low } \\ 2,300 & 2.0 & \text { low } & 1.1 & \text { very low }\end{array}$

Source: ROA

Table 2.8 shows the types of education with low replacement demand, in absolute or relative terms. Two groups of educational types can be distinguished in this table. On the one hand, there are a number of types of education which have only recently become very popular. Some clear examples of this are the tourism courses at both Intermediate Vocational Education and Higher Vocational Education levels and Higher Vocational Education in Commerce, Business administration technology and Commercial information science. What is especially striking is the contrast between the newer 'Higher Economic and Administrative' types of education, Commercial economics and Commercial information science on the one hand and, on the other hand, Accounting, which is a long-established field of study within Higher Economic and Administrative education, and which is expected to experience a high replacement demand. The future replacement demand is also low for Intermediate Vocational Education, Commerce and University Education, Agriculture and environmental science. All of these types of education have a high proportion of relatively young workers, which is expected to lead to fairly low flows out of the labour market in the next few years.

On the other hand, there are also a number of types of Preparatory Vocational Education for which a low replacement demand is expected. These are mainly types of education in which a high proportion of the workers are women. Although many of these women withdraw from the labour market while they are still young, while they are raising children, a considerable proportion of the 
positions which fall vacant in this way are not filled by people with only a Preparatory Vocational Education but rather by school-leavers who have completed a basic qualification at the level of Intermediate Vocational Education or apprenticeship.

\subsection{Job openings and the need for new recruits}

\section{Occupations}

The total number of job openings for newcomers to the labour market consists of the sum of the expansion demand and the flow leaving the labour market. Between 1995 and 2000 employment levels are expected to rise by about 250,000 workers, while slightly more than a million workers will leave the labour market. That implies that $80 \%$ of all net job openings arise because of the need to replace personnel who have left. In addition to these macro flows, there is also mobility between occupational classes. If one counts the 'net occupational mobility' - which does not include flows which cancel each-other out - almost 1.4 million people will leave a vacant position behind them between 1995 and the year 2000. However some of these places will not be filled. In some cases employers use the departure of employees to effect cuts in the number of people of a particular occupational class they employ. Such non-replacement policies will mean that, in the coming five years, a total of almost 170,000 positions which fall vacant will not be filled, so that the total replacement demand for all occupational classes will be about 1.2 million people.

This decline in the employment levels in particular occupational classes is counterbalanced by employment growth in other occupational classes, of 420,000 people. Thus a total of roughly 1.6 million job openings may be expected in the various occupational classes. Of these job openings, $74 \%$ can be ascribed to replacement demand and $26 \%$ to expansion demand. Although the replacement demand is the largest component of total demand, in terms of the number of people employed, the differences between occupational classes are greater with respect to the expansion demand. Thus the expansion demand largely determines which occupational classes will show exceptionally high or low numbers of job openings.

Table 2.9 shows this clearly. The table gives an overview of the occupational classes with the highest numbers of job openings, in absolute or relative terms. The highest number of job openings is expected in the occupational class of managers and supervisors in manufacturing, which relates largely to middle-management positions in industry and construction. This high number of job openings arises mainly because of the expected expansion demand for this occupational class.

In relative terms, the programmers and system analysts are expected to enjoy by far the most job openings, and these are mainly new jobs. Three-quarters of the job openings arise from expansion demand. The other occupational classes with large relative numbers of job openings also exhibit a high or very high expansion demand. In the case of nursing staff, student nurses and home nursing personnel, senior finance and sales managers and journalists and announcers, the replacement demand is also high. 
Table 2.9

Occupational classes with the largest numbers of expected job openings, in absolute or relative terms, 1995-2000 (total numbers and average annual percentages)

$\begin{array}{llll}\text { Occupational class } & \text { forecast } 1995-2000 & & 1990-1994 \\ & \text { number } \% & \text { character. } \% & \text { character. }\end{array}$

absolute

Managers and supervisors in manufacturing

Programmers and system analysts

Sales assistants

Book-keepers and bank employees

Student nurses and home nursing personnel

Purchasing and sales clerks

Secondary and tertiary education teachers

Drivers and conductors

Shopkeepers, retail and wholesale staff

Nursing staff

Commercial reps., buyers and branch managers

Senior finance and sales managers

$\begin{array}{rrlll}126,700 & 7.1 & \text { high } & 3.3 & \text { low } \\ 97,500 & 12.6 & \text { very high } & 4.8 & \text { average } \\ 90,300 & 6.4 & \text { high } & 3.7 & \text { average } \\ 63,200 & 3.3 & \text { average } & 4.5 & \text { average } \\ 52,500 & 7.7 & \text { high } & 5.8 & \text { high } \\ 49,900 & 2.6 & \text { low } & 4.9 & \text { average } \\ 48,700 & 5.6 & \text { average } & 5.0 & \text { average } \\ 48,200 & 4.8 & \text { average } & 7.7 & \text { high } \\ 48,000 & 5.3 & \text { average } & 7.8 & \text { high } \\ 46,200 & 7.6 & \text { high } & 4.1 & \text { average } \\ 44,800 & 6.4 & \text { high } & 3.8 & \text { average } \\ 44,400 & 8.2 & \text { high } & 4.3 & \text { average }\end{array}$

relative

Programmers and system analysts

Journalists and announcers

Accountants and economists

Senior finance and sales managers

Physiotherapists and occupational therapists

Student nurses and home nursing personnel

Nursing staff

Higher electrical engineers

Scientific researchers, technicians and statisticians

Managers and supervisors in manufacturing

Physicians, medical specialists and pharmacists

Agricultural and environmental engineers

$\begin{array}{rrlll}97,500 & 12.6 & \text { very high } & 4.8 & \text { average } \\ 15,400 & 8.5 & \text { very high } & 6.5 & \text { high } \\ 27,500 & 8.3 & \text { very high } & 7.2 & \text { high } \\ 44,400 & 8.2 & \text { high } & 4.3 & \text { average } \\ 13,800 & 7.9 & \text { high } & 3.1 & \text { low } \\ 52,500 & 7.7 & \text { high } & 5.8 & \text { high } \\ 46,200 & 7.6 & \text { high } & 4.1 & \text { average } \\ 5,700 & 7.3 & \text { high } & 2.7 & \text { low } \\ 22,000 & 7.2 & \text { high } & 2.8 & \text { low } \\ 126,700 & 7.1 & \text { high } & 3.3 & \text { low } \\ 15,300 & 6.9 & \text { high } & 7.5 & \text { high } \\ 1,700 & 6.9 & \text { high } & 4.6 & \text { average }\end{array}$

Source: ROA

Most of the occupational classes in Table 2.9 are also the classes for which the employers' recruitment requirements, in absolute or relative terms, will be highest. The exception is the class of book-keepers and bank employees, for which employment is falling, so that the large number of expected job openings does not immediately mean that employers have to recruit many newcomers. In practice, the number of workers in this occupational class is falling, and this is being achieved partly by increasing the flows of workers who leave the labour market or switch to other occupations, through layoffs or threatened layoffs, and through special arrangements for older workers, even though new workers are also being recruited at the same time. Thus, despite these employment cuts, in these cases the positions left vacant by workers who depart are still filled by newcomers to the labour market. This is partly because the demand for people of this occupational class is declining in one business, while the employment levels at other businesses are increasing. Another explanation is that enterprises in which the demand is falling often continue to recruit new workers to meet specific requirements or because of a desire to lower the average age of their personnel. 
Table 2.10

Occupational classes with the lowest numbers of job openings, in absolute or relative terms, 1995-2000 (total numbers and average annual percentages)

$\begin{array}{llll}\text { Occupational class } & \text { forecast } 1995-2000 & & 1990-1994 \\ & \text { number } \% \text { character. } & \% & \text { character. }\end{array}$

absolute

Fishermen and gamekeepers

Electricity and gas supply workers

Sailors, deckhands and engine-room workers

Vetinary surgeons

Datatypists and computer operators

Agricultural and environmental engineers

Ship's officers and marine inspectors

Dentists and dental specialists

Smelter workers and drilling hands

Intermediate electrical engineers

Higher mechanical engineers

Translators and other literary professions

Textile production workers

Wood, paper and cardboard product workers

relative

Fishermen and gamekeepers

Datatypists and computer operators

Sailors, deckhands and engine-room workers

Agricultural workers

Road construction workers and pipelayers

Military professionals

Purchasing and sales clerks

Hairdressers and beauticians

Welders and engineering workers

Technical and medical representatives

Bakers and bakery personnel

Smelter workers and drilling hands

Ship's officers and marine inspectors

$\begin{array}{rlll}3002.0 & \text { very low } & 3.7 & \text { average } \\ 5003.2 & \text { low } & 7.3 & \text { high } \\ 6002.1 & \text { very low } & 4.2 & \text { average } \\ 9005.2 & \text { average } & 5.5 & \text { average } \\ 1,2002.0 & \text { very low } & 0.8 & \text { very low } \\ 1,7006.9 & \text { high } & 4.6 & \text { average } \\ 1,7003.0 & \text { low } & 7.2 & \text { high } \\ 1,7006.1 & \text { high } & 2.8 & \text { low } \\ 1,8003.0 & \text { low } & 1.4 & \text { very low } \\ 1,8005.9 & \text { high } & 8.2 & \text { high } \\ 1,9003.5 & \text { average } & 2.7 & \text { low } \\ 2,0005.7 & \text { average } & 3.7 & \text { average } \\ 2,0004.1 & \text { average } & 4.0 & \text { average } \\ 2,0003.5 & \text { average } & 3.3 & \text { low }\end{array}$

$\begin{array}{rlll}3002.0 & \text { very low } & 3.7 & \text { average } \\ 1,2002.0 & \text { very low } & 0.8 & \text { very low } \\ 6002.1 & \text { very low } & 4.2 & \text { average } \\ 12,3002.2 & \text { very low } & 1.8 & \text { very low } \\ 7,1002.3 & \text { very low } & 0.9 & \text { very low } \\ 3,8002.3 & \text { very low } & 1.8 & \text { very low } \\ 49,9002.6 & \text { low } & 4.9 & \text { average } \\ 4,9002.7 & \text { low } & 3.9 & \text { average } \\ 8,6002.8 & \text { low } & 2.0 & \text { very low } \\ 3,5002.9 & \text { low } & 30.9 & \text { very high } \\ 3,3002.9 & \text { low } & 3.7 & \text { average } \\ 1,8003.0 & \text { low } & 1.4 & \text { very low } \\ 1,7003.0 & \text { low } & 7.2 & \text { high }\end{array}$

Source: ROA

With one exception, the occupational classes with the fewest job openings in relative terms all face declining demand, which means that the number of job openings for newcomers is entirely determined by the replacement demand. The exception is the class of technical and medical representatives, where the low number of job openings is mainly the result of the very low replacement demand. Table 2.10 shows that six occupational classes offer very low numbers of job openings. These occupational classes have both a negative expansion demand and a very low replacement demand.

\section{Types of education}

Table 2.11

Types of education with the largest numbers of job openings, in absolute or relative terms, 1995-2000 (total numbers 


$\begin{array}{lll}\text { Type of education } & \text { forecast 1995-2000 } & 1990-1994\end{array}$

number \% character. \% character.

absolute

IVE, Retail

HVE, Teacher training

Primary Education

Lower General Secondary Education

Higher General Secondary Education

IVE, nursing and paramedical services

IVE, Community care

PVE, Community care, hotel and catering

HVE, Social and cultural

IVE, Construction technology

UE, Social sciences

HVE, Nursing and paramedical services

relative

UE, Economics, econometrics and business admin.

UE, Electrical engineering and information tech.

UE, Management science

UE, Information science

HVE, Commercial information science

UE, Theology

HVE, Accounting

UE, Mathematics and natural sciences

PVE, Security

UE, Mechanical engineering

UE, Veterinary and medical sciences and dentistry

UE, Construction and civil engineering

$\begin{array}{llll}86,1005.0 & \text { average } & 5.0 & \text { average } \\ 69,4005.1 & \text { average } & 4.2 & \text { average } \\ 68,9002.6 & \text { low } & 1.4 & \text { very low } \\ 55,8002.6 & \text { low } & 1.8 & \text { very low } \\ 53,7003.3 & \text { average } & 3.9 & \text { average } \\ 50,7005.2 & \text { average } & 3.5 & \text { low } \\ 40,6003.5 & \text { average } & 4.1 & \text { average } \\ 39,1003.6 & \text { average } & 2.1 & \text { low } \\ 32,4005.3 & \text { average } & 4.6 & \text { average } \\ 32,0003.6 & \text { average } & 3.0 & \text { average } \\ 29,1006.7 & \text { high } & 5.8 & \text { high } \\ 27,7006.2 & \text { high } & 4.6 & \text { average }\end{array}$

$\begin{array}{rlll}22,6009.3 & \text { very high } & 7.0 & \text { high } \\ 6,6008.7 & \text { very high } & 5.5 & \text { high } \\ 4,7008.5 & \text { very high } & 4.8 & \text { average } \\ 2,0008.3 & \text { very high } & 5.7 & \text { high } \\ 13,3008.2 & \text { very high } & 4.8 & \text { average } \\ 2,4008.1 & \text { very high } & 6.3 & \text { high } \\ 12,5008.1 & \text { very high } & 5.9 & \text { high } \\ 17,6007.7 & \text { high } & 4.5 & \text { average } \\ 4,3007.6 & \text { high } & 7.3 & \text { high } \\ 3,5007.4 & \text { high } & 3.9 & \text { average } \\ 20,7007.2 & \text { high } & 3.2 & \text { average } \\ 7,2007.2 & \text { high } & 6.8 & \text { high }\end{array}$

Source: ROA

Table 2.11 shows the types of education with the highest total numbers of job openings for newcomers to the labour market, in absolute or relative terms. Almost all types of education with the highest expected numbers of job openings in absolute terms are in educational categories which are very large in terms of present employment levels, but for which the number of job openings in relative terms is only average or low. The fact that they are large means that there is a large replacement demand in absolute terms, but they are no longer growing strongly.

The types of education with the most job openings in relative terms are not so large. The list of these types of education consists entirely of higher education courses. Although many of these types of education also enjoy a relatively high replacement demand, for most of them the majority of the job openings result from very high expansion demand. The exception in this respect is University Education, Theology, for which the large number of job openings is mainly due to the very high need for replacement workers.

The types of education with the most job openings in relative terms are also those for which 
employers' recruitment requirements, in relative terms, will be the greatest. Because none of these types of education face any fall in demand, there is in this case no question of an entire group of workers who are more or less being forced to leave the labour market. 
Table 2.12

Types of education with the lowest numbers of job openings, in absolute or relative terms, $1995-2000$ (total numbers and average annual percentages)

$\begin{array}{llll}\text { Type of education } & \text { forecast } 1995-2000 & 1990-1994 \\ \text { number } \% & \text { character. } \% & \text { character. }\end{array}$

absolute

PVE, Printing trades

HVE, Tourism and recreation

IVE, Tourism and recreation

PVE, Utilities installation

UE, Pharmacy

PVE, Commerce

PVE, Food trades

HVE, Police, fire and defense

HVE, Interpreter and translator

UE, Information science

UE, Theology

UE, Fine Arts

relatively

PVE, Commerce

IVE, Tourism and recreation

PVE, Food trades

PVE, Administration

PVE, Automobile trades

PVE, Printing trades

PVE, Electrical trades

PVE, Construction trades

PVE, Utilities installation

IVE, Secretarial

HVE, Tourism and recreation

Primary Education

Lower General Secondary Education

IVE, Agriculture and the natural environment number $\%$ character. \% character.

Source: ROA

The types of education with the fewest job openings, in absolute or relative terms, are listed in Table 2.12. Most of these types of education face negative expansion demand, which means that the number of job openings is almost entirely dependent on the need to replace departing workers. The exception to this is education in Tourism and recreation at Intermediate Vocational Education and Higher Vocational Education level. The limited number of job openings for those with these types of education results mainly from the very low replacement demand, combined with the modest size of these educational categories in the labour market.

In relative terms, the number of job openings for Preparatory Vocational Education in Commerce, Food trades and Administration and Intermediate Vocational Education in Tourism and recreation, which has just been mentioned, is very low. The need for replacement workers from all three types of education is very low. 


\subsection{Flows of school-leavers entering the labour market}

Thus far, this chapter has considered only the future changes on the demand side of the labour market. But in fact the changes in expansion and replacement demand must be matched with changes on the supply side of the labour market. In addition to the supply of short-term unemployed who were waiting on the edge of the market at the beginning of the forecast period, the most important factor here is the flow of school-leavers entering the labour market.

Table 2.13 gives an overview of the types of education for which the expected flows of schoolleavers are highest, in absolute or relative terms. Naturally the list of types of education with the largest numbers of school-leavers is dominated by the large types of education. The greatest number of school-leavers will come from Intermediate Vocational Education, Retail, which will deliver a total of almost 90,000 school-leavers to the labour market in the next five years. But in relative terms this inflow is not so large. Almost as many school-leavers with a Higher General Secondary Education most of them drop-outs from higher education, will enter the labour market.

The list of types of education which will produce the largest flows of school-leavers in relative terms gives a better picture of the dynamics of the flows entering the labour market. The flows coming from all ten of these types of education are very high. In relative terms, the largest flow of graduates will come from Higher Vocational Education, Commerce, with an average annual inflow amounting to almost $10 \%$ of the number of workers who had this educational background and were employed in the previous year. This high flow rate is a continuation of the rapid buildup of school-leaver numbers in the first half of the nineties. The expected inflow rates for the non-regular Preparatory Vocational Education in Security are almost as high, and this type of education was also one of the fastest-growing types in previous years. However this non-regular course is the only lower-level course for which the flow of school-leavers entering the labour market is relatively high.

With the exception of Preparatory Vocational Education, Security, all of the types of education for which the flow of school-leavers entering the market are expected to be relatively high fall within higher education. Courses in management and economics are especially well represented. This would indicate that the high flows entering the labour market from these types of education over recent years will continue in the coming years, although the numbers entering the labour market will clearly decline in comparison with the flows in the first half of the nineties. The same may be said for University Education, Information science and University Education, Law.

Table 2.13

Types of education with the highest flows of school-leavers entering the labour market, in absolute or relative terms, 1995-2000 (total numbers and average annual percentages)

$\begin{array}{llll}\text { Type of education } & \text { forecast } 1995-2000 & 1990-1994 \\ \text { number } \% \quad \text { character. } \% & \text { character. }\end{array}$

absolute

IVE, Retail

$89,500 \quad 5.0 \quad$ average $\quad 3.5$

average 
Higher General Secondary Education

IVE, Community care

Primary Education

IVE, nursing and paramedical services

HVE, Teacher training

HVE, Social and cultural

IVE, Electrical technology

IVE, Construction technology

IVE, Administration

UE, Social sciences

Lower General Secondary Education

relative

HVE, Commerce

PVE, Security

UE, Management science

HVE, Business administration technology

UE, Fine Arts

UE, Mechanical engineering

UE, Information science

HVE, Business administration

UE, Law

UE, Economics, econometrics and business admin.

UE, Arts

UE, Electrical engineering and information tech.

$\begin{array}{lllll}87,500 & 5.1 & \text { average } & 6.5 & \text { high } \\ 62,700 & 5.2 & \text { high } & 5.2 & \text { average } \\ 46,900 & 1.8 & \text { low } & 1.9 & \text { low } \\ 44,800 & 4.5 & \text { average } & 5.7 & \text { high } \\ 39,900 & 2.9 & \text { average } & 2.7 & \text { low } \\ 31,400 & 4.9 & \text { average } & 3.2 & \text { average } \\ 29,000 & 3.7 & \text { average } & 4.5 & \text { average } \\ 27,600 & 3.1 & \text { average } & 3.8 & \text { average } \\ 26,800 & 5.2 & \text { high } & 7.7 & \text { very high } \\ 26,500 & 5.8 & \text { high } & 6.0 & \text { high } \\ 24,500 & 1.2 & \text { low } & 1.6 & \text { low }\end{array}$

\begin{tabular}{|c|c|c|c|c|}
\hline 12,300 & 9.8 & very high & 10.4 & very high \\
\hline 6,000 & 9.6 & very high & 9.2 & very high \\
\hline 5,700 & 9.4 & very high & 6.9 & high \\
\hline 6,500 & 8.6 & very high & 7.3 & very high \\
\hline 4,200 & 8.1 & very high & 7.1 & very high \\
\hline 4,100 & 8.1 & very high & 5.2 & average \\
\hline 1,800 & 7.5 & very high & 8.1 & very high \\
\hline 9,200 & 7.2 & very high & 7.4 & very high \\
\hline 18,800 & 6.9 & very high & 8.3 & very high \\
\hline 17,200 & 6.9 & very high & 7.0 & very high \\
\hline 15,400 & 6.3 & high & 8.0 & very high \\
\hline 4,800 & 6.2 & high & 6.1 & high \\
\hline
\end{tabular}

Source: ROA

The expected relative inflow of university graduates in mechanical engineering is remarkably high in comparison with the other higher technical types of education. In previous years the flows entering the labour market from this type of education were no higher than the average level, and were lower than the flows coming from University Education, Electrical engineering, which at that time had the highest graduate output, in relative terms, of all the technical types of higher education. It is also striking that the flow coming from Fine Arts education at the university level remains remarkably high, despite the bad labour market prospects which graduates from this type of education have long faced.

Table 2.14 gives an overview of the types of education with the smallest flows entering the labour market, in absolute or relative terms. The list of the types of education with the smallest inflows of school-leavers in absolute terms is naturally dominated by the smaller types of education. The lower part of the table, which is based on relative magnitudes, gives a clearer picture of the types of education for which the flows entering the labour market are small. This list is largely dominated by the lower types of education. This indicates that the employment cuts at the lower end of the labour market are in most cases coupled with smaller flows of people with lower-level education entering the labour market. It can be seen that the flows coming onto the labour market from Preparatory Vocational Education, Electrical trades, Transport and harbour, Community care, hotel and catering, Agriculture and Construction trades, and from Lower General Secondary Education and Primary Education, are quite limited in comparison with the number of existing workers with the relevant educational backgrounds, even though the numbers of school-leavers concerned are quite substantial, especially if one considers those with Lower General Secondary Education and the school-leavers with only primary education. The decline in the relative flows of school-leavers who 
come onto the labour market with only lower education is in most cases a continuation of the trend over recent years. It is primarily the result of declining student numbers in Preparatory Vocational Education and Lower General Secondary Education. The number of people entering the labour market from Preparatory Vocational Education in particular, has declined drastically.

Table 2.14

Types of education with the smallest flows of school-leavers entering the market, in absolute or relative terms, 19952000 (total numbers and average annual percentages)

$\begin{array}{lll}\text { Type of education } & \text { forecast } 1995-2000 & \text { 1990-1994 } \\ \text { number } \% \text { character. } \% & \text { character. }\end{array}$

absolute

UE, theology

\begin{tabular}{|c|c|c|c|}
\hline 6002.3 & low & 1.8 & low \\
\hline $1,1002.8$ & average & 3.5 & average \\
\hline $1,3000.4$ & very low & 0.5 & very low \\
\hline $1,3000.9$ & low & 1.4 & low \\
\hline $1,3005.3$ & high & 6.0 & high \\
\hline $1,4003.0$ & average & 2.5 & low \\
\hline $1,5003.1$ & average & 3.0 & average \\
\hline $1,7002.1$ & low & 3.2 & average \\
\hline $1,7004.0$ & average & 4.2 & average \\
\hline $\begin{array}{lll}1,800 & 0.7\end{array}$ & very low & 1.2 & low \\
\hline $1,8007.5$ & very high & 8.1 & very high \\
\hline $1,9002.2$ & low & 3.3 & average \\
\hline
\end{tabular}

PV, Printing trades

PVE, Electrical trades

HVE, Transport and harbour

UE, Pharmacy

HVE, Interpreter and translator

PVE, Utilities installation

IVE, Precision engineering

HVE, Tourism

IVE, Legal and fiscal

UE, Information science

IVE, Process technologies

number $\%$ character. \% character.

relative

PVE, Electrical trades

IVE, Legal and fiscal

HVE, Transport and harbour

PVE, Transport and harbour

Lower General Secondary Education

PVE, Community care, hotel and catering

PVE, Agriculture

HVE, Accounting

Primary Education

PVE, Construction trades

PVE, Mechanical trades

IVE, Precision engineering

$\begin{array}{rllll}1,300 & 0.4 & \text { very low } & 0.5 & \text { very low } \\ 1,800 & 0.7 & \text { very low } & 1.2 & \text { low } \\ 1,300 & 0.9 & \text { low } & 1.4 & \text { low } \\ 2,200 & 1.2 & \text { low } & 1.1 & \text { low } \\ 24,500 & 1.2 & \text { low } & 1.6 & \text { low } \\ 13,9001.3 & \text { low } & 1.6 & \text { low } \\ 6,600 & 1.7 & \text { low } & 0.9 & \text { very low } \\ 2,5001.7 & \text { low } & 1.5 & \text { low } \\ 46,9001.8 & \text { low } & 1.9 & \text { low } \\ 14,2002.0 & \text { low } & 2.1 & \text { low } \\ 14,800 & 2.1 & \text { low } & 2.3 & \text { low } \\ 1,7002.1 & \text { low } & 3.2 & \text { average }\end{array}$

Source: ROA

The list of the types of education with the most limited relative flows of school-leavers entering the labour market also includes Higher Vocational Education, Transport and harbour and Accounting and Intermediate Vocational Education, Legal and fiscal. For Higher Vocational Education, Accounting this is because only a few of those who undertake commercial and administrative education at the Higher Vocational Education level are choosing to study accounting. Moreover, the Higher Vocational Education students who study accounting through the Dutch Institute of Registered Accountants are counted as university-educated once they have reached a level equivalent to a Masters degree. 


\subsection{Crowding-out processes}

The analysis of expansion demand by type of education which was described in section 2.2 included an allowance for expected shifts in the educational structure of occupations. In practice such shifts very often come down to an upgrading of the qualification structure of the occupation in question. Changes in educational structure were also taken into consideration in calculating the replacement demand by type of education, because the departure of personnel with a particular educational background does not automatically lead to a need for a replacement worker from the same type of education.

These shifts in the demand for labour with a particular educational background, in relation to the changing supply of school-leavers, lead to discrepancies between demand and supply. This means that it is not possible to meet the demand for workers of some educational categories, while there is excess supply in other educational categories. In practice, as was noted in section 2.1, such disequilibriums in the labour market do not automatically mean a corresponding increase in the number of unfilled vacancies or the number of unemployed, respectively. The labour market is in many cases sufficiently flexible to absorb a large part of these disequilibria. People with an educational background which is in excess supply switch to other occupations and generally accept less generous wages and less favourable conditions of employment. If there is a supply shortage, on the other hand, they can be more demanding about the work that they will accept. Equally, employers who face recruitment problems will often recruit people with another educational background, whereas in the event of excess supply they will raise their requirements.

This switching to other labour categories is only possible if those concerned compromise as regards the sort of work they will do and the wages for it, or as regards workers' required educational backgrounds. This active substitution is therefore a manifestation of an imbalance in the relationship between demand and supply. This is why this switching process is not considered in determining the labour market prospects and the risks of problems in recruiting labour, which are in fact intended precisely to highlight these matching problems in the labour market. 
Table 2.15

Types of education which are being crowded out by other types of education to a marked degree, in absolute or relative terms (total numbers and average annual percentages)

Type of education forecast $1995-2000 \quad 1990-1994$ number $\%$ character. \% character.

absolute

Primary Education

PVE, Community care, hotel and catering

IVE, Agriculture and the natural environment

PVE, Construction trades

PVE, Mechanical trades

Lower General Secondary Education

IVE, Community care

PVE, Agriculture

IVE, Construction technology

IVE, Retail

IVE, Hotel, catering and hairdressers

PVE, Transport and harbour

$\begin{array}{llrl}-8,800-0.3 & \text { average } & 0.0 & \text { average } \\ -8,600-0.9 & \text { low } & -0.7 & \text { average } \\ -6,800-1.0 & \text { low } & -1.2 & \text { low } \\ -6,000-0.9 & \text { low } & -0.2 & \text { average } \\ -5,800-0.9 & \text { low } & -0.6 & \text { average } \\ -5,600-0.3 & \text { average } & -0.2 & \text { average } \\ -5,500-0.5 & \text { average } & -0.4 & \text { average } \\ -5,200-1.4 & \text { low } & -1.2 & \text { low } \\ -5,200-0.6 & \text { average } & 0.0 & \text { average } \\ -2,900-0.2 & \text { average } & -0.2 & \text { average } \\ -2,400-0.8 & \text { low } & -0.1 & \text { average } \\ -2,300-1.3 & \text { low } & -1.0 & \text { low }\end{array}$

relative

PVE, Agriculture

PVE, Transport and harbour

PVE, Utilities installation

PVE, Textile and leather trades

IVE, Agriculture and the natural environment

PVE, Construction trades

PVE, Mechanical trades

PVE, Automobile trades

PVE, Community care, hotel and catering

PVE, Food trades

IVE, Hotel, catering and hairdressers

$\begin{array}{rlll}-5,200-1.4 & \text { low } & -1.2 & \text { low } \\ -2,300-1.3 & \text { low } & -1.0 & \text { low } \\ -500-1.2 & \text { low } & -0.1 & \text { average } \\ -1,100-1.0 & \text { low } & -0.8 & \text { low } \\ -6,800-1.0 & \text { low } & -1.2 & \text { low } \\ -6,000-0.9 & \text { low } & -0.2 & \text { average } \\ -5,800-0.9 & \text { low } & -0.6 & \text { average } \\ -2,200-0.9 & \text { low } & -0.7 & \text { average } \\ -8,600-0.9 & \text { low } & -0.7 & \text { average } \\ -8,00-0.8 & \text { low } & -0.8 & \text { low } \\ -2,400-0.8 & \text { low } & -0.1 & \text { average }\end{array}$

Source: ROA

'i.e., 'negative passive substitution'

The actual number of job openings for the types of education which suffer from crowding-out by other types of education which are in excess supply will in fact be reduced as a result of this crowding out process, while those types of education which are closely related to types of education for which there is a supply shortage will benefit from extra employment opportunities. Thus these passive substitution effects certainly are significant in determining the labour market prospects of the school-leavers from these types of education and they are therefore taken into account in the forecasts of their labour market prospects.

Table 2.15 gives an overview of the types of education which will suffer most from crowding out by other types of education. The table shows that quite a large number of jobs are lost as a result of these crowding-out processes in the labour market, especially for workers without any educational qualifications or qualifications at the levels of Preparatory Vocational Education or Lower General Secondary Education and Intermediate Vocational Education/apprenticeship. But this crowding-out is expected to reduce the demand for workers with these lower types of education to only a limited 
degree in the coming years because of the generally quite favourable developments in the labour market. If economic growth or the numbers of workers withdrawing from the labour market should turn out to be lower, many jobs would be lost, especially where those without any educational qualifications or with only Preparatory Vocational Education are crowded out by people with Intermediate Vocational Education. ${ }^{20}$ Chapter 4 will examine these crowding-out processes in the labour market in more detail.

${ }^{20}$ This can be seen in A.G.M. Matheeuwsen, W. Smits, E.J.T.A. Willems, Trendrapport arbeidsmarkt technisch opgeleiden (Report on trends in the labour market for people with technical education), ROA-R-1994/12, Maastricht, 1994, which was based on lower levels of economic growth. 


\section{The match between education and labour market}

\subsection{Current matching problems}

The discrepancy between the educational profile of the supply of labour and the qualifications which are demanded on the labour market can be described most clearly on the basis of the unemployment rate and the extent of under-utilization for each type of education. The unemployment rate gives an indication of the 'visible discrepancies' in the labour market, while the extent to which workers are employed in functions that are beneath their level gives an impression of the 'hidden discrepancies'. In addition to these indicators, which can be immediately interpreted, matching problems on the labour market also manifest themselves in the forms of lower wages, less favourable conditions of employment and involuntary part-time work. However this chapter will discuss the current matching problems in the labour market only on the basis of the level of unemployment and the degree of under-utilization ('over-education'). ${ }^{21}$

Table 3.1 presents unemployment rates by educational level. Unemployment among people who have only primary education is very high, and for people with an education at the level of Preparatory Vocational Education the unemployment rate is also higher than average. Unemployment is lowest among those with an education at Higher Vocational Education level.

Table 3.1

Unemployed labour force by educational level, 1994

Educational level $\%$

Primary Education 17.0

Lower General Secondary Education/Preparatory Vocational Education 10.3

Higher General Secondary Education, Intermediate Vocational Education and apprenticeship $\quad 6.9$

Higher Vocational Education

University Education

Total

Source: CBS

Of course unemployment will also differ strongly between the various fields of study, but there are no figures for unemployment differentiated by type of education for the labour force as a whole. There is data about the unemployment among school-leavers for a large number of the types of education differentiated in this report. Table 3.2 shows the unemployment among school-leavers from General Secondary Education, Preparatory Vocational Education and Intermediate Vocational Education on the basis of the RUBS school-leavers' survey. Table 3.3 shows the unemployment among graduates from Higher Vocational Education, based on the Higher Vocational Education Monitor, while Table 3.4 presents unemployment figures for university graduates who graduated

${ }^{21}$ In chapter 5 other aspects of the current labour market situation will also be explored for some types of Intermediate Vocational Education (see also part III of the Statistical Appendix). 
after 1978, on the basis of a study of unemployment among those with higher education in $1993^{22}$ The figures in these three tables cannot be directly compared with one another, because they are based on surveys held at various times and the groups covered by the surveys are also not fully comparable. The RUBS survey approaches school-leavers about nine months after the end of their education. For the Higher Vocational Education Monitor there is, on average, about 18 months between the end of the education and the time of the survey, while the figures for University Education relate to all graduates since 1978 .

Table 3.2 shows that the unemployment among school-leavers from Lower General Secondary Education, Preparatory Vocational Education and Intermediate Vocational Education varies very much. Unemployment among people with Lower General Secondary Education is very high compared to the other types of education at the level of Preparatory Vocational Education and Intermediate Vocational Education or apprenticeship. There are also some Intermediate Vocational Education courses whose school-leavers suffer high unemployment: Intermediate Vocational Education, Process technologies and Intermediate Vocational Education, Technical Laboratory. On the other hand, Intermediate Vocational Education, Transport and harbour and Preparatory Vocational Education, Printing trades have very low unemployment.

Table 3.2

Unemployment among school-leavers from General Secondary Education, Preparatory Vocational Education and Intermediate Vocational Education, 1994

Type of education

Lower General Secondary Education

PVE, Agriculture

PVE, Construction trades

PVE, Utilities installation

PVE, Mechanical trades

PVE, Automobile trades

PVE, Electrical trades

PVE, Printing trades

PVE, Food trades

PVE, Textile and leather trades

PVE, Transport and harbour

PVE, Administration

PVE, Commerce

PVE, Community care, hotel and catering

PVE, Security

Higher General Secondary Education

IVE, Agriculture and the natural environment

IVE, Technical Laboratory
$\%$

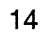

8

6

6

10

10

11

10

11

6

2

12

${ }^{22}$ See M.S.M. Van Smoorenburg and R.K.W. Van der Velden, Schoolverlaters op de arbeidsmarkt, De uitstroom en bestemming van het schooljaar 1992-1993 (School-leavers on the labour market, the outflows and destinations for the school year 1992-1993), LDC, Leeuwarden, 1995; P.J.E. Van de Loo, J. Hoevenberg, R.K.W. Van der Velden, HBO-Monitor 1994 (Higher Vocational Education Monitor 1994), Higher Vocational Education Council, Den Haag, 1995; and A.C. Van der Neut, M.E. Veldhoen and J.F.M. De Jonge, De werkloosheid onder hoger opgeleiden in 1993 (Unemployment among those with higher education in 1993), Ministry of Education and Science, Den Haag, 1994, respectively. 
IVE, Construction technology

IVE, Civil engineering

IVE, Metalworking

IVE, Precision engineering

IVE, Mechanical engineering 
Table 3.2 (continued)

Unemployment among school-leavers from General Secondary Education, Preparatory Vocational Education and Intermediate Vocational Education, 1994

IVE, Automobile technology

IVE, Electrical technology

IVE, Printing technology

IVE, Food technology

IVE, Process technologies $\quad 15$

IVE, Textile and leather technology

IVE, Transport and harbour

IVE, Nursing and paramedical services 5

IVE, Medical laboratory

IVE, Retail

IVE, Administration $\quad 10$

IVE, Tourism and recreation

IVE, Commerce 9

IVE, Secretarial

IVE, Legal and fiscal

IVE, Social and cultural $\quad 11$

IVE, Community care

IVE, Hotel, catering and hairdressers 9

IVE, Police, fire and defense

- = not known

Source: RUBS 1994/ROA

* according to the definition of 'registered unemployment'

Table 3.3

Unemployment among school-leavers from Higher Vocational Education, 1994

HVE, Interpreter and translator

HVE, Agriculture and environmental science 11

HVE, Technical laboratory $\quad 19$

HVE, Construction and civil engineering 6

HVE, Mechanical engineering $\quad 15$

HVE, Electronic and information technology 18

HVE, Transport and harbour 9

HVE, Medical laboratory $\quad 11$

HVE, Nursing and paramedical services 5

HVE, Business administration $\quad 7$

HVE, Accounting 4

HVE, Commercial information science 8

HVE, Tourism and recreation $\quad 10$

HVE, Commerce -

HVE, Business administration technology 18

HVE, Legal and fiscal $\quad 11$

HVE, Social and cultural

HVE, Fine Arts 20

HVE, Police, fire and defense 
- = not known

Source: Higher Vocational Education monitor 1994/ROA

* according to the definition of 'registered unemployment'

For Higher Vocational Education, unemployment is particularly high among recent graduates in the fields of Fine Arts, Technical laboratory, Business administration technology and Electronic and information technology. In contrast, unemployment is very low among graduates from Higher Vocational Education in Accounting, Nursing and paramedical services and Construction and civil engineering.

Table 3.4 shows that for University Education, the highest unemployment is found among graduates in the fields of Fine Arts and Arts (i.e., humanities). Unemployment is also relatively high for graduates from University Education, Agriculture. For the University Education courses in Construction and civil engineering, Veterinary and medical sciences and dentistry, Pharmacy, Information science and Public administration, on the other hand, unemployment is very low.

Table 3.4

Unemployment among university graduates (since 1978), 1993

Type of education

$\%$

UE, Arts 11

UE, Theology 6

UE, Agriculture and environmental science $\quad 9$

UE, Mathematics and natural sciences $\quad 6$

UE, Construction and civil engineering 1

UE, Mechanical engineering 4

UE, Electrical engineering and information technology 3

UE, Veterinary and medical sciences and dentistry 2

UE, Pharmacy 2

UE, Economics, econometrics and business administration 3

UE, Management sciences $\quad 6$

UE, Information science 2

UE, Law

UE, Public administration 2

UE, Social sciences

UE, Fine Arts 13

Source: Research voor Beleid (Research for Policy)

* according to the definition of 'registered unemployment'

Table 3.5 gives an overview of the types of education with the highest percentages of workers who are actually working at a lower job level than would be expected on the basis of their educational level. Some relationship would be expected between the level of unemployment and the degree to which people with a particular education are under-utilized. The higher the unemployment, the more willing people will be to accept a job below their level. The table shows that the rate of underutilization is very high for five types of education. Of the workers with an educational background at the level of Preparatory Vocational Education, those trained in the fields of Transport and harbour and Security suffer very much from under-utilization. At the level of Intermediate Vocational 
Education and apprenticeship, there is a great deal of under-utilization for those who have studied Process technologies and Textile and leather technologies. At the level of Higher Vocational Education there is a very high rate of under-utilization for Tourism and recreation. The types of education with a high rate of under-utilization are all at the level of Preparatory Vocational Education or Intermediate Vocational Education and apprenticeship. So far as this can be observed, the unemployment rate is also considerably higher than average for most of these types of education. However this is not true for Intermediate Vocational Education, Community care, Intermediate Vocational Education, Transport and harbour or, to a lesser extent, Intermediate Vocational Education, Metalworking and Preparatory Vocational Education, Community care, hotel and catering. Perhaps the rate of unemployment in these cases is not so high precisely because people accept jobs below their educational level.

It can be concluded that matching problems are located mainly at the lower end of the labour market. Unemployment is highest for people who have only primary education and for those with an education at the level of Lower General Secondary Education or Preparatory Vocational Education. But large differences between the various fields of study are indeed observable. Thus there are also a number of types of education at the level of Higher Vocational Education and University Education which have relatively high unemployment. Under-utilization is found mainly among people at Preparatory Vocational Education and Intermediate Vocational Education or apprenticeship level.

Table 3.5

Types of education with the highest rates of under-utilization, 1994

Type of education

$\% \quad$ characterization

PVE, Transport and harbour

very high

HVE, Tourism and recreation

very high

IVE, Process technologies

very high

PVE, Security

IVE, Textile and leather technology

IVE, Food technology

PVE, Community care, hotel and catering

PVE, Textile and leather trades

very high

very high

high

high

high

IVE, Community care

IVE, Tourism and recreation

IVE, Printing technology

high

high

IVE, Police, fire and defense

PVE, Commerce

IVE, Transport and harbour

PVE, Food trades

IVE, Metalworking

high

high

high

high

high

high

Source: ROA/CBS

\subsection{Labour market prospects for school-leavers}

As was indicated in Figure 2.1, an indication of any future matching problems which can be expected in the labour market can be given on the basis of forecasts from the developments in demand and supply in the labour market which were outlined in chapter 2 . This is done by means of 
the Indicator of the Future Labour market situation (IFL), which shows the ratio between the supply and the corresponding demand, so far as these are relevant for school-leavers, for each type of education. In contrast to the other qualitative characterizations which are used in this report, the IFL characterizations are given in four classes. If the supply is smaller than demand, and the IFL is thus less than 1.00, the labour market prospects are characterized as 'good'. If the IFL lies between 1.00 and 1.05, which is to say that the excess supply is not much above what could be regarded as the frictional level, the prospects are called 'reasonable'. If the excess supply is even higher, the prospects are called 'moderate' or, if the IFL is above 1.15, 'bad'.

\section{Types of education with good prospects}

Table 3.6 shows the types of education which are expected to have good labour market prospects. The table shows that it is mainly types of education at the level of Higher Vocational Education and University Education which have good labour market prospects. But even at the Preparatory Vocational Education level there are a number of types of education with good prospects: Preparatory Vocational Education, Transport and harbour and Preparatory Vocational Education, Community care, hotel and catering. The good prospects for these types of education are due to relatively low inflows of school-leavers and relatively high replacement demand. It is striking, however, that both types of education are at the moment suffering from high rates of underutilization. This means that a large part of the predicted demand relates to work at a low qualification level. However the favourable relationship between demand and supply presumably implies that school-leavers with training in these fields will in the future be more able to avoid these jobs.

The good prospects for those with education in Transport and harbour at the Intermediate Vocational Education and apprenticeship level is also due to the relatively high replacement demand. At this level there are also a number of technical types of education with good labour market prospects: Intermediate Vocational Education, Precision engineering, Printing technology and Textile and leather technologies. For all of these types of education, the weak expansion demand is more than outweighed by the high replacement demand. The prospects for Intermediate Vocational Education Police, fire and defense, Nursing and paramedical services and Medical laboratory are especially good because they have a higher expansion demand than other types of education at the Intermediate Vocational Education and apprenticeship level. Finally, for Intermediate Vocational Education, Legal and fiscal the good prospects are mainly due to the inadequate flows of school-leavers entering the labour market.

Most types of education at the level of Higher Vocational Education have good labour market prospects. The best prospects are for Higher Vocational Education, Accounting, followed by Higher Vocational Education, Commercial information science. The expansion demand for these types of education is, in relative terms, very high. Moreover, for Higher Vocational Education, Accounting there is also a very high replacement demand and a low flow of school-leavers entering the labour market.

For Higher Vocational Education, Technical laboratory and the other technical types of education at the level of Higher Vocational Education the good prospects are mainly due to the relatively high 
number of job openings, as a result of both the high expansion demand and the high replacement demand. But Higher Vocational Education, Mechanical engineering and Higher Vocational Education, Electronic and information technology do have somewhat higher IFL ratios, because the flows of school-leavers entering the market from these types of education are somewhat higher than the flows from other technical types of education at the Higher Vocational Education level.

The good prospects for Higher Vocational Education, Transport and harbour are due to the inadequate inflows of school-leavers with this type of education. Both Higher Vocational Education, Medical laboratory and Higher Vocational Education, Nursing and paramedical services will enjoy high expansion demand. In addition, the flows entering the market from Higher Vocational Education, Medical laboratory are relatively low.

Table 3.6

Types of education with good labour market prospects in 2000

Lower General Secondary Education, Preparatory Vocational Education

PVE, Transport and harbour $\quad 0.97$

$\begin{array}{ll}\text { PVE, Community care, hotel and catering } & 0.99\end{array}$

Higher General Secondary Education, Intermediate Vocational Education

IVE, Legal and fiscal 0.91

IVE, Precision engineering $\quad 0.93$

IVE, Medical laboratory $\quad 0.94$

IVE, Police, fire and defense $\quad 0.95$

IVE, Transport and harbour $\quad 0.98$

IVE, Printing technology $\quad 0.99$

IVE, Textile and leather technology $\quad 1.00$

$\begin{array}{ll}\text { IVE, Nursing and paramedical services } & 1.00\end{array}$

Higher Vocational Education

HVE, Accounting $\quad 0.73$

HVE, Commercial information science $\quad 0.77$

HVE, Transport and harbour $\quad 0.79$

HVE, Construction and civil engineering $\quad 0.83$

HVE, Technical laboratory $\quad 0.85$

HVE, Medical laboratory $\quad 0.91$

HVE, Fine Arts $\quad 0.91$

HVE, Legal and fiscal $\quad 0.92$

HVE, Teacher training 0.93

HVE, Electronic and information technology $\quad 0.94$

HVE, Nursing and paramedical services $\quad 0.94$

$\mathrm{HVE}$, Interpreter and translator $\quad 0.95$

HVE, Mechanical engineering $\quad 0.98$

HVE, Social and cultural $\quad 0.99$

HVE, Police, fire and defense $\quad 0.99$

University Education

$\begin{array}{ll}\text { UE, Construction and civil engineering } & 0.76\end{array}$ 


$\begin{array}{ll}\text { UE, Theology } & 0.79 \\ \text { UE, Mathematics and natural sciences } & 0.83 \\ \text { UE, Veterinary and medical sciences and dentistry } & 0.83 \\ \text { UE, Electrical engineering and information technology } & 0.86 \\ \text { UE, Economics, econometrics and business administration } & 0.88 \\ \text { UE, Public administration } & 0.88 \\ \text { UE, Information science } & 0.93 \\ \text { UE, Social sciences } & 0.97 \\ \text { UE, Pharmacy } & 0.98 \\ \text { UE, Agriculture and environmental science } & 1.00 \\ \text { UE, Mechanical engineering } & 1.00\end{array}$

Source: ROA

The good labour market prospects for Higher Vocational Education, Legal and fiscal can be attributed mainly to the very high replacement demand. The same applies to Higher Vocational Education, Teacher training. The good labour market prospects for Higher Vocational Education, Fine Arts, which are due to the relatively high expansion demand, are striking. Other types of education at this level which offer good labour market prospects are Higher Vocational Education, Social and cultural, Higher Vocational Education, Police, fire and defense and Higher Vocational Education, Interpreter and translator.

With only a few exceptions, the labour market prospects for university graduates are good. For most types of education at the university level, the good labour market prospects are due to the relatively high number of job openings. For University Education in Economics, econometrics and business administration, Public administration and Information science there is a very high expansion demand. While there is a very high flow of graduates from University Education, Economics, econometrics and business administration entering the labour market, there are expected to be even more job openings for newcomers. In recent years the high inflows of economists have led to less favourable prospects, but at that time the growth in the number of jobs for people with this type of education was less. As a result, economists have had problems in recent years as regards the match between education and labour market. ${ }^{23}$

There is a very large replacement demand for those with University Education, Mathematics and natural sciences. Of the technical types of education at university level, University Education, Construction and civil engineering has the best labour market prospects. The number of job openings for graduates in this field is relatively high, while the expected inflow is relatively low, especially in comparison with the other technical types of education at the university level. The expected flows of graduates entering the labour market in the fields of Mechanical engineering and Electrical engineering and information technology are relatively high, but will still be less than the relatively high numbers of job openings.

The good prospects for University Education, Theology are almost entirely due to the very high replacement demand. For University Education, Veterinary and medical sciences and dentistry, not

${ }^{23}$ See G.W.M. Ramaekers, Arbeidsmarktscanner Rijksuniversiteit Limburg: Basismeting cohort'92 (The Labour market scanner for the University of Limburg, base-line measurement for the cohort of 92), ROA-R-1994/7, Maastricht, 1994. 
only is the replacement demand quite high, the expansion demand is also high. In addition, University Education, Social sciences and University Education, Agriculture and environmental science also have good labour market prospects. For both types of education, both the replacement demand and the expansion demand are high.

\section{Types of education with bad labour market prospects}

Table 3.7 shows that only a limited number of types of education are expected to offer bad future labour market prospects for newcomers to the labour market. It is striking that there is at least one type of education at every educational level which offers bad prospects for newcomers to the labour market.

The bad prospects for Preparatory Vocational Education, Food trades is mainly attributable to the very low replacement demand and the negative expansion demand. Moreover, school-leavers from this type of education are being crowded out of their traditional occupational domain by schoolleavers from other types of education. For Intermediate Vocational Education, Tourism and recreation, a relatively high flow of school-leavers entering the labour market is coupled with a limited number of job openings for newcomers to the labour market, mainly because of the very low replacement demand. The labour market prospects for school-leavers from Higher Vocational Education, Commerce, Intermediate Vocational Education, Automobile technology and Intermediate Vocational Education, Social and cultural are also bad, because of a combination of high flows entering the labour market and a limited number of job openings for newcomers. For Preparatory Vocational Education, Commerce, the bad labour market prospect result from the very small number of job openings for newcomers to the labour market, which is due largely to the very low replacement demand.

\section{Table 3.7}

Types of education with bad prospects in 2000

Lower General Secondary Education, Preparatory Vocational Education

PVE, Food trades $\quad 1.29$

$\begin{array}{ll}\text { PVE, Commerce } & 1.22\end{array}$

Higher General Secondary Education, Intermediate Vocational Education

IVE, Tourism and recreation $\quad 1.26$

IVE, Automobile technology $\quad 1.22$

$\begin{array}{ll}\text { IVE, Social and cultural } & 1.20\end{array}$

Higher Vocational Education

HVE, Commerce $\quad 1.22$

University Education

UE, Fine Arts 
Source: ROA

\subsection{Future problems in the labour supply}

If a particular type of education has good labour market prospects, it will be relatively easy for school-leavers with this education to find a job. On the other hand, it will be difficult for employers to recruit school-leavers with this educational background. Good labour market prospects for schoolleavers thus entail a high risk of problems in recruiting labour for employers. An Indicator of the Future Risks of Labour recruitment problems (IFRL) has been compiled to give an indication of the possible future recruitment problems as regards the various types of education. As was shown in section 2.1, this indicator will differ from the IFL only for those types of education which face declining employment. In that case employers may take the opportunity to reduce the compulsory redundancies among their existing personnel, which will lead to a reduction in the inflows of newcomers which they require. ${ }^{24}$ If the IFRL is less than or equal to 0.95 , the risk of problems in recruiting labour is characterized as high.

In discussing the types of education which can be expected to face recruitment problems, an indication will be given in each case of the economic sectors in which these problems are likely to arise. ${ }^{25}$ Just as unfavourable labour market prospects for newcomers to the labour market do not automatically imply high unemployment, recruitment problems cannot simply be equated with the existence of vacancies which cannot be filled. As was noted previously, employers can respond to these problems in various ways: by offering higher wages, improving the image of the work, recruiting workers with other educational backgrounds, working overtime, and so forth. Thus recruitment problems indicate, in the first place, an increase in the costs or efforts which employers will face if they wish to employ a worker from the type of education in question.

At the level of Intermediate Vocational Education and apprenticeship, the only types of education for which the risk of future labour recruitment problems is considered to be high are Intermediate Vocational Education, Legal and fiscal, Precision engineering, Medical laboratory and Police, fire and defence. People with Intermediate Vocational Education, Legal and fiscal work mainly in the civil service, police, defense and education sector and, to a lesser extent, in the sector of other commercial services. These sectors may in the future be handicapped by the inadequate flows of people with this educational background entering the labour market, although it must also be noted that the intermediate administrative occupations, in which $70 \%$ of the people with Intermediate Vocational Education, Legal and fiscal legal work, are becoming less important in these sectors. Problems in recruiting those with Intermediate Vocational Education, Precision engineering will manifest themselves mainly in the sector of metal and electrical industries, in which more than $30 \%$ of the people with this educational background work, and in commerce, which provides employment for more than $20 \%$ of the people with this educational background. The expected recruitment

\footnotetext{
${ }^{24}$ In practice this results in only a few differences from the indicator values given in Table 3.6. For a complete overview see Table 3.30 of the Statistical appendix.

${ }^{25}$ For the present purposes this must be based on a simple criterion: only the economic sectors in which at least $10 \%$ of all workers with the educational background concerned work will be mentioned.
} 
problems for Intermediate Vocational Education, Medical laboratory will be felt mainly in the commercial sector and the health care sector, in which $80 \%$ of the people with this educational background work.

As for higher education, most of the problems are expected to arise for the economic, technical and medical types of education, leaving aside the almost traditional problems in recruiting newcomers from University Education, Theology. The expected shortages for Higher Vocational Education, Accounting and Higher Vocational Education, Commercial information science could lead to problems particularly in 'other commercial services'. In particular the higher economic and administrative occupations, such as accountants, economists, programmers and system analysts, in which more than $30 \%$ of the people with Higher Vocational Education in Accounting and more than $60 \%$ of the people with Higher Vocational Education in Commercial information science work, will grow strongly in the coming years in this sector. The financial services sector and the civil service, police, defense and education sector may also face problems as a result of shortages of people with this educational background.

The other commercial services and the civil service, police, defense and education sector are also very likely to face problems in recruiting people with University Education in Economics, econometrics and business administration and in Information science. More than $30 \%$ of the people with University Education, Economics, econometrics and business administration work in the other commercial services sector, and $20 \%$ work in the civil service, police, defense and education sector. Another $15 \%$ work in financial services. They are found mainly in higher economic and administrative occupations.

People with University Education, Public administration and Higher Vocational Education, Legal and fiscal work chiefly in the civil service, police, defense and education sector and the other commercial services sector, mainly in the higher economic and administrative occupations and in the higher public policy, legal and fiscal occupations, for example as civil servants (public administration) or legal professionals. The expected problems will arise especially in the higher economic and administrative occupations, because employment in the public policy, legal and fiscal occupations is expected to decline in coming years, while employment in the higher economic and administrative occupations is expected to grow strongly.

Likewise, for University Education, Construction and civil engineering and Higher Vocational Education, Construction and civil engineering, the problems will be felt in the sectors of other commercial services and the civil service, police, defense and education. For Higher Vocational Education, Construction and civil engineering, problems are also likely to be felt in the construction sector. People with an education in Construction and civil engineering frequently work as architects and construction engineers. Employment for these occupations is growing particularly in the civil service, police, defense and education sector and in the construction sector. In addition, many people with Higher Vocational Education or University Education in Construction and civil engineering work in intermediate technical and industrial occupations, for example as managers and supervisors in manufacturing and as technical draughtsmen. Employment in these occupations is increasing in the construction sector, in other commercial services, and in the civil service, police, defense and education sector. For those with Higher Vocational Education in Transport and 
harbour, the expected recruitment problems will be felt mainly in the Transport, storage and communication sector and, to a lesser degree, also in the other commercial services sector.

For University Education, Electrical engineering and information technology and Higher Vocational Education, Electronic and information technology the largest recruitment problems are to be expected in the sectors of metal and electrical industries and other commercial services, in which more than half of the people with an education in electrical engineering and information technology at either the University or Higher Vocational Education level work. Problems may be expected to arise in commerce, especially as regards those with Higher Vocational Education in this field. People with this educational background work chiefly as higher electrical engineers and as programmers and system analysts. Employment for programmers and system analysts is growing strongly in both the other commercial services sector and the metal and electrical industries sector. The higher level occupations in electrical and electronic fields are growing strongly only in the metal and electrical industries sector.

For University Education, Mathematics and natural sciences and Higher Vocational Education, Technical laboratory, the greatest problems will be felt in the sector of the Civil service, police, defense and education. For those with university education in the field of mathematics and natural sciences, these problems will probably be felt particularly in the education system itself. In addition the sectors of non-commercial services and other commercial services may face recruitment problems as regards both types of education, while the chemicals sector will suffer particularly from the expected short supply of technical laboratory technicians at Higher Vocational Education level.

In the coming years the health care sector is expected to face recruitment problems in relation to three types of higher education: University Education, Veterinary and medical sciences and dentistry, Higher Vocational Education, Medical laboratory and Higher Vocational Education, Nursing and paramedical services. The occupational classes on which these types of education are focused are expected to continue to grow vigorously in the future.

The expected problems in the labour market for those with Higher Vocational Education, Fine Arts are striking. These problems are mainly the result of the high expansion demand, especially in the non-commercial services sector, where almost half of the workers with this educational background are employed. In addition, the sectors of other commercial services and the civil service, police, defense and educational sector (particularly as regards education) may suffer from these labour supply problems.

Finally, labour supply problems are also expected for those with Higher Vocational Education, Teacher training. For this type of education, the rather specific demands as regards qualifications lead to strongly differentiated labour market segments, so that recruitment problems for teachers in one field may occur alongside an excess supply of teachers in another field. The expected supply shortages for the other types of higher education would suggest that the shortages of teachers will be felt mainly in the technical and economic studies. 